\title{
Capturing the Invisible Resource: Analysis of Waste Heat Potential in Chinese Industry
}

\author{
Hongyou LU a1, Lynn PRICE a, Qi ZHANG ${ }^{b}$ \\ ${ }^{a}$ Energy Technologies Area, Energy Analysis and Environmental Impacts Division \\ Lawrence Berkeley National Laboratory, Berkeley, CA, USA \\ ${ }^{\mathrm{b}}$ SEPA Key Laboratory on Eco-industry, Northeastern University, Shenyang, Liaoning, China
}

\begin{abstract}
Waste heat recovery and utilization represents a missed opportunity to reduce China's total energy use, decrease carbon dioxide emissions, and improve air quality. Currently, China does not have a standardized or transparent methodology to quantify the waste heat potential in the industrial sector, which accounts for more than two thirds of China's primary energy consumption. This paper presents the results of thermal energy modeling to quantify the technical maximum waste heat potential in three energy-intensive industrial sectors: cement, iron and steel, and glass. In addition, this paper identifies the practical potential for producing electricity from waste heat in these sectors. The analysis finds that the glass sector has the highest waste heat to power generation potential per unit of production basis among the studied sectors. This paper provides key principles for managing waste heat in the industrial sector and key sector characteristics for implementing waste heat to power generation technologies.
\end{abstract}

Key words: waste heat potential; waste heat to power generation; industry; China.

\section{Introduction}

Many industrial processes generate unused or waste heat during manufacturing. Depending upon a number of factors, such as industry characteristics, fuel inputs, and operational practices, industrial waste heat accounts for $10 \%$ to $50 \%$ of total fuel consumption in various industrial sectors. Waste heat can be a valuable energy source if it is managed well. Through waste heat utilization, waste heat can be used to provide electricity, steam, space heating, and hot water.

In China, the potential to improve industrial waste heat management is significant. The industrial sector is the largest energy consumer and carbon dioxide $\left(\mathrm{CO}_{2}\right)$ emitting end-use sector in China, representing about 70\% of China's total primary energy use and energy-related

${ }^{1}$ Hongyou Lu: 1 Cyclotron Road, Mailstop 90R2121, Berkeley, CA 94702. Email: hylu@lbl.gov 
$\mathrm{CO}_{2}$ emissions in 2012 (NBS, 2013a; IPCC, 2006). In addition, coal is the dominant fuel supply in Chinese industry, accounting for about 71\% of total fuel use in 2012 (NBS, 2013a). The industry sector is one of the most important sectors to address in order to reduce air pollutants, such as sulfur oxides (SOx), nitrogen oxides (NOx), and particulate matter, in China. Improving waste heat utilization in China's industry sector not only can reduce overall coal consumption but also can provide significant environmental and public health benefits.

Improving waste heat utilization supports China's targets related to energy and emissions. On November 12, 2014, in a joint statement with the United States, China announced its intention to peak $\mathrm{CO}_{2}$ emissions around 2030 while striving to peak earlier (The White House, 2014). Achieving this goal will require China to install an additional 800 to $1,000 \mathrm{GW}$ of zero-emission electricity generation capacity by 2030 (Podesta and Holdren, 2014). The growth of coal consumption is also targeted to decrease, as China set a goal of reducing the share of coal in total energy consumption to below $65 \%$ by 2017 (China State Council, 2013). In the $12^{\text {th }}$ FiveYear Plan (FYP) for 2011-2015, China is expected to reduce the national energy intensity (energy use per unit of GDP) and carbon intensity ( $\mathrm{CO}_{2}$ emissions per unit of GDP) by $16 \%$ and

\subsection{Why this study is needed?}

The concept of waste heat as a resource is similar to the concepts of oil reserves or wind power resources. However, the industrial waste heat resource is much more fragmented than other energy sources. The waste heat resource is dispersed geographically at the industrial plant level. Also, the supply and reliability of waste heat may fluctuate over time, mainly due to changes in industrial production or mismatches between supply and demand. In addition, the temperature and composition of the waste heat carrier streams varies from site to site.

There is a general consensus on the significance of the waste heat potential in industrial sectors. However, the literature on this topic reports minimal waste heat potential in only a few sectors in China, such as the cement sector. Technical analysis of waste heat potential of a full array of energy-intensive sectors in China does not exist at this time. More importantly, for those studies that have been conducted, the reported waste heat utilization potential is often presented without a clearly explained methodology. The use of vague and inconsistent methodologies across different sectors significantly impairs the ability of researchers, investors, or policymakers to accurately understand the reported waste heat potential.

This paper aims to fill the research gaps by identifying the available waste heat potential in key energy-intensive sectors in China through the use of a consistent and transparent methodology. Specifically, this paper focuses on waste heat to power generation and the primary objective is to analyze the technical potential of waste heat in three sectors: cement, iron and steel, and glass. In the sections below, the paper first summarizes the methods used for the technical potential analysis. Then, data, assumptions, and results are presented on the waste heat potential in the three sectors, including both the waste heat potential and the potential to produce electricity from waste heat. Lastly, this paper summarizes key technical findings, identifies research limitations, and describes needs for future research. 


\subsection{Review of international studies on waste heat potential}

82 From a whole-society, whole-system perspective, in 1971, Earl Cook estimated that about 50\%

83 of the energy input to the U.S. society was lost as waste heat (Cook, 1971). This included energy

84 losses from all sectors, such as power generation and industrial manufacturing. This study

85 highlighted the need to understand the potential of waste heat. A later study conducted by the US Environmental Protection Agency (EPA) relied on EPA's National Emissions Data System, which collected stack temperatures from industrial sources, including boilers, internal combustion devices, and industrial processes (US EPA, 1984). The study found that about $30 \%$ of industrial input was lost as waste heat in 1974, and about $3 \%$ of the waste heat is available for recovery (at a temperature higher than $150^{\circ} \mathrm{C}\left(300^{\circ} \mathrm{F}\right)$ ). However, this study used the stack temperature (from the emission database) instead of the exhaust gas temperature exiting the equipment. Stack temperature is normally much lower than exhaust temperature; thus, the findings of waste heat potential may very likely be underestimated.

Besides the studies conducted about 30-40 years ago (US EPA, 1984; Cooke, 1971), the United States Department of Energy (US DOE) and the Pacific Northwest National Laboratory (PNNL) conducted waste heat potential analyses in 2004, 2006, and 2008 (Energetics and E3M, 2004; PNNL, 2006; US DOE, 2008). The 2004 study identified key areas for improving energy efficiency and reducing energy losses in the US manufacturing sectors. Based on approximate assumptions on energy efficiency and improvement potential, it estimated about $20-50 \%$ of heat was lost (Energetics and E3M, 2004). The 2005 study conducted by PNNL focused on opportunities for recovering energy from chemical emissions and thermal emissions, such as the chemical energy in unburned carbon dioxide and methane (PNNL, 2006).

The latest waste heat potential study conducted by US DOE was in 2008. This study analyzed the technical potential based on an enthalpy analysis, taking into account energy inputs, temperatures, and heat recovery practices. The study found the waste heat practical potential in aluminum, iron and steel, glass, cement, metal casting, boilers, and ethylene furnaces to be $5 \%, 6 \%, 23 \%, 11 \%, 33 \%, 6 \%$, and $5 \%$, of the energy use of that sector, respectively (US DOE, 110 2008).

Most recently, Oluleye et al. (2015) developed a methodology to identify waste heat potential in industry. This study illustrated the methodology by using a case study from a refinery. It would be useful for policy makers and other researchers if this methodology could be applied to other industrial sectors, regions, or countries using actual industry, regional, or country data and information. Miró et al. (2015) collected industrial waste heat data from 33 countries and 6 sub-regions. The study identified that there is a lack of specification when reporting industrial waste heat data, which made data comparison of industrial waste heat potentials across countries difficult. This paper also recognized that there is a lack of data on industrial waste heat potential in Asian countries, especially China. While this paper's intention was not to estimate the industrial waste heat potential of a specific industry or country, it did provide recommendations on how the data should be reported, i.e., including the type of industrial waste heat potential, the methodology for calculating industrial waste heat potential, reference temperatures, year of data used, liquid or gas state of industrial waste heat, and boundaries 
125 and scope of studies on industrial waste heat. Brückner et al. (2015) provided an overview of

126 industrial waste heat potential, including definitions, main technologies, possible industrial

127 waste heat sources, and temperatures of waste heat. This paper focused on an economic

128 analysis of waste heat recovery technologies (including absorption chillers, electrical heat

129 pumps, and absorption heat pumps) and estimated the maximum acceptable investment costs

130 of each technology assessed. However, this analysis did not evaluate industry-specific potential

131 or provide any discussion of the potential in China.

Besides governmental and research organizations, consulting companies also published estimations of waste heat potential. Frost \& Sullivan (2010) estimated the potential of waste heat in the United States. This study showed a much higher percentage of heat being wasted in the studied sectors, on average about $20 \%, 49 \%, 40 \%$, and $19 \%$ in aluminum (primary), oil refining, steel, and pulp and paper sectors, respectively (Frost \& Sullivan, 2010). However, the methodology used to estimate the waste heat potential is not clearly described in the report.

The Norwegian utility Enova published a study in 2009 to assess the "usable waste heat potential" of the Norwegian industry by sending out questionnaires to 105 energy-intensive companies including the food processing, wood processing, cement and building block processing, chemistry, aluminum, and ferro alloy industries. Together, these companies represent about $63 \%$ of the Norwegian final energy consumption. The study received about $69 \%$ responses ( 72 companies out of 105 companies answered). The study reported that for metal production, basic chemistry, and processing of stone and earth, the waste heat (temperature at or above $140^{\circ} \mathrm{C}$ ) potential of the final energy use is estimated to be $30 \%, 8 \%$, and $40 \%$, respectively (Sollesnes and Helgerud, 2009).

In Germany, two-thirds of final industrial energy use was used to produce process heat in 2007. Based on a Norwegian study's findings of percentages of waste heat potential in certain industries (Sollesnes and Helgerud, 2009), researchers in Germany estimated that the technoeconomic potential of waste heat (at a temperature above $140^{\circ} \mathrm{C}$ ) in Germany is higher than $12 \%$ of the annual industrial energy use (Pehnt et al., 2011). The potential for medium-low temperature waste heat $\left(60^{\circ} \mathrm{C}-140^{\circ} \mathrm{C}\right)$ is estimated to be $6 \%$ of total industrial energy use in Germany (Pehnt et al., 2011).

These studies were conducted for different purposes and for different countries (e.g., the United States, Germany, Norway) but all found a significant industrial waste heat energy-

160 savings potential. Depending on different manufacturing processes, fuel types, and technologies adopted, the waste heat potential could be as low as $3 \%$ to as much as $50 \%$ of total energy input (Table 1). This review of these studies highlights the need to establish a standardized methodology that can incorporate sector-level specifics, such as energy inputs,

164 technology efficiency, and exhaust temperatures into the analysis. 
168 waste heat potential through questionnaires and field research. This study analyzed seven 169 industrial products including cement, steel, glass, ammonia, caustic soda, calcium carbide, and 170 sulfuric acid. It found that the waste heat potential ranged from $15 \%$ to $40 \%$ of the total fuel 171 input, depending on the studied product/sector (ERI, 2011). Compared to many other reports 172 and articles on China's waste heat potential, this study was one of the most comprehensive. 173 However, it still relied heavily on self-reporting, assumed percentages for recovery rates, and 174 assumed waste heat potential per unit of production.

176 Lu (2010) provided estimates of additional waste heat to power capacities in the cement, glass, 177 iron and steel, chemicals, and non-ferrous metals sectors in China. Zhou (2012) provided 178 information on estimated waste heat potential in seven sectors in China, but without a clearly 179 explained methodology. Dong (2013) summarized the current status of waste heat utilization in 180 industrial sectors based on a literature research, but did not provide analysis of the waste heat 181 potential. 
182 Table 1. International Studies on Waste Heat Potential

\begin{tabular}{|c|c|c|c|c|}
\hline Reviewed literature & Scope & Methods & Findings & Limitations \\
\hline Cook (1971) & $\begin{array}{l}\text { All sectors in the US, including energy } \\
\text { production, transmission, distribution, } \\
\text { and end-use sectors. }\end{array}$ & $\begin{array}{l}\text { Comparing energy input of the } \\
\text { whole society to end-use energy } \\
\text { consumption }\end{array}$ & $\begin{array}{l}\text { About } 50 \% \text { of energy inputs lost as waste } \\
\text { heat }\end{array}$ & $\begin{array}{l}\text { Lack of sector-specific details; conducted } \\
\text { over } 40 \text { years ago }\end{array}$ \\
\hline US EPA (1984) & $\begin{array}{l}\text { Industrial sectors and power generation in } \\
\text { the United States, such as boilers, internal } \\
\text { combustion devices; industrial processes. }\end{array}$ & $\begin{array}{l}\text { Based on US EPA emission database } \\
\text { and stack temperature }\end{array}$ & $\begin{array}{l}\text { About } 30 \% \text { of industrial inputs lost as } \\
\text { waste heat; about } 3 \% \text { could be recovered } \\
\text { at a temperature above } 150^{\circ} \mathrm{C}\left(300^{\circ} \mathrm{F}\right)\end{array}$ & $\begin{array}{l}\text { Final exhaust temperature may be lower } \\
\text { than furnace exit temperatures; } \\
\text { conducted over } 30 \text { years ago }\end{array}$ \\
\hline $\begin{array}{l}\text { Energetics and E3M } \\
(2004)\end{array}$ & $\begin{array}{l}\text { Energy-intensive sectors in the US, } \\
\text { including mining, chemicals, petroleum } \\
\text { refining, forest products, iron and steel, } \\
\text { food, and cement sectors. }\end{array}$ & $\begin{array}{l}\text { Based on assumptions of thermal } \\
\text { energy efficiency and improvement } \\
\text { potential }\end{array}$ & $\begin{array}{l}\text { About } 20-50 \% \text { of energy was lost in } \\
\text { studied sectors }\end{array}$ & $\begin{array}{l}\text { Lack of detailed waste heat analysis; } \\
\text { based on assumptions of efficiency and } \\
\text { improvement potential }\end{array}$ \\
\hline PNNL (2006) & $\begin{array}{l}\text { Focused on chemical and thermal } \\
\text { emissions from industrial processes (such } \\
\text { as chemical, glass, and cement) in the US }\end{array}$ & $\begin{array}{l}\text { Survey of existing literature to } \\
\text { determine the amount of energy } \\
\text { embedded in the emissions }\end{array}$ & $\begin{array}{l}\text { Non-CO2 greenhouse gas emissions in } \\
\text { industry represented about } 4.3 \% \text { of total } \\
\text { energy used in the US industry }\end{array}$ & $\begin{array}{l}\text { Focused on chemical energy content in } \\
\text { emissions; lack of detailed analysis of } \\
\text { waste heat potential }\end{array}$ \\
\hline US DOE (2008) & $\begin{array}{l}\text { Aluminum, iron and steel, glass, cement, } \\
\text { metal casting, boilers, and ethylene } \\
\text { furnaces in the United States }\end{array}$ & $\begin{array}{l}\text { Enthalpy analysis based on energy } \\
\text { input and waste heat temperature }\end{array}$ & $\begin{array}{l}\text { Practical potential of waste heat ranges } \\
\text { from } 5 \text { to } 33 \% \text { of total energy input in } \\
\text { industrial sectors }\end{array}$ & $\begin{array}{l}\text { Lack of economic analysis; Lack of real- } \\
\text { world assumptions on waste heat to } \\
\text { power conversion }\end{array}$ \\
\hline $\begin{array}{l}\text { Sollesnes and } \\
\text { Helgerud (2009) }\end{array}$ & $\begin{array}{l}\text { Food processing, wood processing, } \\
\text { cement and building block processing, } \\
\text { chemistry, aluminum, and Ferro alloy } \\
\text { industries in Norway }\end{array}$ & $\begin{array}{l}\text { Questionnaires to } 105 \text { energy- } \\
\text { intensive companies (response rate: } \\
63 \% \text { ) }\end{array}$ & $\begin{array}{l}\text { About } 30 \%, 8 \% \text {, and } 40 \% \text { of waste heat } \\
\text { potential }\left(\geq 140^{\circ} \mathrm{C} \text { or } 284^{\circ} \mathrm{F}\right) \text { in metal } \\
\text { production, basic chemistry, and } \\
\text { processing of stone and earth sectors, } \\
\text { respectively }\end{array}$ & $\begin{array}{l}\text { Industry self-reporting; lack of } \\
\text { standardized and transparent } \\
\text { methodology }\end{array}$ \\
\hline $\begin{array}{l}\text { Frost \& Sullivan } \\
(2010)\end{array}$ & $\begin{array}{l}\text { Aluminum, oil refining, steel, and pulp and } \\
\text { paper sectors in the United States }\end{array}$ & Unclear & $\begin{array}{l}\text { About } 20-50 \% \text { of energy input being } \\
\text { wasted as heat in the studied sectors }\end{array}$ & $\begin{array}{l}\text { Consulting report; Unclear } \\
\text { methodologies; Lack of analysis on } \\
\text { practical technical potential }\end{array}$ \\
\hline Pehnt et al. (2011) & $\begin{array}{l}\text { Energy-intensive sectors in Germany, such } \\
\text { as metal production, basic chemicals, } \\
\text { commercial paper, food processing, } \\
\text { processing of stone and earth, and glass } \\
\text { and ceramics. }\end{array}$ & $\begin{array}{l}\text { Assigning percentages of waste heat } \\
\text { potential based on previous studies } \\
\text { and author opinions }\end{array}$ & $\begin{array}{l}\text { Waste heat potential ranges from } 3 \% \text { to } \\
40 \% \text { depending on manufacturing sectors }\end{array}$ & $\begin{array}{l}\text { Based on other country's studies; lack of } \\
\text { in-country analysis; lack of standardized } \\
\text { methodology }\end{array}$ \\
\hline $\begin{array}{l}\text { Brückner et al. } \\
(2015)\end{array}$ & $\begin{array}{l}\text { Overview of industrial waste heat } \\
\text { potential; economic analysis of three } \\
\text { waste heat recovery technologies }\end{array}$ & $\begin{array}{l}\text { Economic analysis on payback time } \\
\text { and return on investment }\end{array}$ & $\begin{array}{l}\text { Estimated the maximum acceptable } \\
\text { investment costs of each technology } \\
\text { assessed }\end{array}$ & $\begin{array}{l}\text { Did not evaluate industry-specific } \\
\text { potential or provide any discussion of the } \\
\text { potential in China }\end{array}$ \\
\hline Miró et al. (2015) & $\begin{array}{l}\text { Collected aggregated waste heat potential } \\
\text { from } 33 \text { countries and six sub-regions }\end{array}$ & Data collection, literature review & $\begin{array}{l}\text { Recommendations on industrial waste } \\
\text { heat potential studies }\end{array}$ & $\begin{array}{l}\text { Limited data for Asian countries, } \\
\text { especially for China }\end{array}$ \\
\hline Oluleye et al. (2015) & $\begin{array}{l}\text { Modeling of four types of waste heat } \\
\text { recovering technologies; and a case study } \\
\text { from a refinery plant }\end{array}$ & $\begin{array}{l}\text { Modeling of four waste heat } \\
\text { recovering technologies }\end{array}$ & $\begin{array}{l}\text { Identify ways to maximize site energy } \\
\text { efficiency while recovering industrial } \\
\text { waste heat }\end{array}$ & $\begin{array}{l}\text { Limited application of the methodology } \\
\text { in different sectors or different countries }\end{array}$ \\
\hline
\end{tabular}


Table 2. Chinese Studies on Waste Heat Potential

\begin{tabular}{|c|c|c|c|c|}
\hline $\begin{array}{l}\text { Reviewed } \\
\text { literature }\end{array}$ & Scope & Methods & Findings & Limitations \\
\hline Lu (2010) & $\begin{array}{l}\text { Waste heat to power } \\
\text { capacities in cement, glass, } \\
\text { iron and steel, chemicals, and } \\
\text { non-ferrous metals sectors. }\end{array}$ & $\begin{array}{l}\text { Literature review and } \\
\text { author estimation }\end{array}$ & $\begin{array}{l}\text { Estimated additional waste } \\
\text { heat to power capacities in } \\
\text { selected sectors }\end{array}$ & $\begin{array}{l}\text { Lack of analysis on waste heat } \\
\text { potential }\end{array}$ \\
\hline ERI (2011) & $\begin{array}{l}\text { Energy intensive sectors in } \\
\text { China, including iron and steel, } \\
\text { cement, glass, ammonia, } \\
\text { caustic soda, calcium carbide, } \\
\text { and sulfuric acid. }\end{array}$ & $\begin{array}{l}\text { Questionnaires and } \\
\text { onsite field research }\end{array}$ & $\begin{array}{l}\text { Waste heat potential is } \\
\text { about } 15-40 \% \text { of total fuel } \\
\text { input in the selected } \\
\text { industries }\end{array}$ & $\begin{array}{l}\text { Based on specific energy intensity } \\
\text { and assume percentages of waste } \\
\text { heat; did not consider waste heat } \\
\text { to power penetration rates }\end{array}$ \\
\hline Zhou (2012) & $\begin{array}{l}\text { Seven energy-intensive } \\
\text { sectors in China, such as } \\
\text { cement, iron and steel, and } \\
\text { ammonia. }\end{array}$ & Unclear & $\begin{array}{l}\text { Waste heat potential is } \\
\text { about } 10-50 \% \text { of total fuel } \\
\text { input; } 54 \% \text { of waste heat is } \\
\text { medium-low temperature } \\
\left(<400^{\circ} \mathrm{C} \text {, or } 752^{\circ} \mathrm{F}\right)\end{array}$ & $\begin{array}{l}\text { Unclear methodology; lack of } \\
\text { sectoral detailed analysis }\end{array}$ \\
\hline Dong (2013) & $\begin{array}{l}\text { Iron and steel, non-ferrous } \\
\text { metals, chemicals, buildings } \\
\text { materials, and light industries } \\
\text { in China }\end{array}$ & Literature review & $\begin{array}{l}\text { Current waste heat } \\
\text { utilization status in the } \\
\text { studied sectors }\end{array}$ & $\begin{array}{l}\text { Lack of analysis on waste heat } \\
\text { potential }\end{array}$ \\
\hline
\end{tabular}




\section{Methods and Data Sources}

\subsection{Thermal energy modeling}

A thermal energy-modeling tool was developed to estimate the technical potential for waste heat utilization. The method used in the model is thermal enthalpy analysis, as shown in Equation (1), which takes into account fuel inputs, combustion conditions, exhaust gas temperatures, reference temperatures, and types of technologies (US DOE, 2008).

$E_{\text {waste heat }}=\left(m_{\text {exhaust gas }}\right) \times \sum_{i}\left(x_{i} \times h_{i}(t)\right)$

where:

$E_{\text {waste heat }}$ : thermal energy in waste heat

$m_{\text {exhaust gas }}$ : mass flow of exhaust gas

i: species of gases in the exhaust gas

$x_{i}$ : mass fraction of gas $i$ in the exhaust gas

$h_{i}(t)$ : enthalpy of gas $i$ in the exhaust gas at temperature difference of $t$

$t$ : temperature difference between the exhaust temperature and the reference temperature

Waste heat potential can be quantified by multiplying the mass flow rate of the exhaust gas with the enthalpy of the exhaust gas, as indicated in Equation (1). The mass flow rate of the exhaust gas can be determined by fuel consumption and combustion equations. The enthalpy can be determined by comparing the exhaust gas temperature to a reference temperature. This analysis used two reference temperatures; thus, two levels of waste heat potential are calculated: 1) a theoretical maximum waste heat potential, reducing the temperature of the waste heat to ambient temperature $\left(25^{\circ} \mathrm{C}\left[77^{\circ} \mathrm{F}\right]\right)$ and capturing all possible thermal energy in the waste heat, and 2 ) a practical waste heat potential, reducing the temperature of the waste heat to $150^{\circ} \mathrm{C}\left(300^{\circ} \mathrm{F}\right)$ and capturing a significant portion of the thermal energy.

Based on the thermal energy potential of waste heat, this analysis also determined three levels of waste heat to power generation potential, varying in its efficiency of converting thermal energy into electricity: 1) "power generation at current efficiency", representing the most practical amount of power that could be produced, based on the practical waste heat potential and current (real-world) power generation efficiency; 2) "power generation approaching Carnot Efficiency", referring to a theoretical situation where the practical waste heat potential is converted to power at the rate of Carnot Efficiency (Carnot Efficiency determines the maximum amount of power that could be produced theoretically); and 3) "power generation approaching Carnot Efficiency with max heat recovery", referring to a theoretical situation where the maximum waste heat potential is converted to power at the rate of Carnot Efficiency. Based on expert interviews and a 2004 report (Energetics and E3M, 2004), this study assumed in practice about $20 \%$ of the waste heat potential can be converted to electricity. 
The predominant fuel input in Chinese industries is coal. Given the complexity in coal composition and coal types, this analysis assumed coal used in the studied industries has an average lower heating value of $5,500 \mathrm{kcal} / \mathrm{kg}(9,980 \mathrm{Btu} / \mathrm{lb})$. This assumption is based on the most common purchased coal type in China and crossed check with the information found in 58 Chinese cement plants (Price et al., 2009; LBNL and CBMA, 2012). Typical coal composition from China is used, i.e., $11 \%$ water content and $18 \%$ ash content (Wang and $L i, 2001$ ). In addition, this analysis also considered heavy fuel oil and used a typical lower heating value of 9,700 $\mathrm{kcal} / \mathrm{kg}(17,470 \mathrm{Btu} / \mathrm{lb})$. Lastly, this analysis assumed that there is about $3 \%$ oxygen remaining after the combustion process is completed.

\subsection{Expert interviews} Expert interviews were conducted to cross check data inputs and key assumptions made in the modeling process. Key assumptions include exhaust gas temperatures and penetration levels of existing waste heat to power technologies in China. Interviewees were international energy experts, industry experts, professors, and researchers working in the field of cogeneration, the cement industry, the iron and steel sector, and in energy services consulting. Examples of interviewees are professors from Northeastern University in China and the University of Science and Technology - Beijing, cement experts from the China Cement Association, and U.S. experts specialized in cogeneration, steam systems, and process heating systems.

\section{3.}

\section{Cross-examination of data}

Cross-examination methods were used to cross check the outputs from the thermal energy modeling. The methods used include comparing model outputs to reported Chinese data and comparing to the results from estimating the differences between the theoretical minimum energy intensity and the practical energy intensities of the various industries.

\subsection{Data sources} Industrial energy use data in China mostly is provided in the China Energy Statistical Yearbook published by the National Bureau of Statistics (NBS) annually. Sectoral data, such as production by technology and by process, comes from sectoral yearbooks published by related industrial associations. Exhaust temperatures of current production processes as well as thermal efficiency and cost data for waste heat to power technologies are based on both literature review and interviews with industry experts in the U.S. and China. Penetration levels for current use of waste heat to power technologies relied on published government technology catalogues, industrial association surveys, interviews with experts, and literature research. Energy intensity levels for the studied sectors relied on the Chinese minimum energy efficiency standards (MEPS) for industrial products (AQSIQ and SAC, 2008; AQSIQ and SAC, 2012; AQSIQ and SAC, 2013).

263 Similar to the general waste management principle of "Reduce, Recycle, and Reuse", waste

264 heat management should follow the principle of "Reduce, Recycle, and Recover" (Figure 1). 
Sources of waste heat can be reduced through upgrading process equipment, reducing waste heat losses, and increasing system efficiency. Depending on the nature of the process and industry characteristics, industry can adopt measures such as combustion optimization, process controls, insulation improvement, minimizing openings, and implementing energy management systems. The goal is to reduce the release of waste heat as a by-product of manufacturing processes.

Waste heat can be recycled within the heating system for use in the manufacturing processes. Typically, waste heat can be used to preheat combustion air or make-up air, preheat fuel (in limited cases), and preheat charging materials. Due to its low investment cost and high energyefficiency, it is commonly recommended to consider recycling waste heat for process use first.

\section{Figure 1. Waste Heat Management}

- Minimize waste heat

- e.g., combustion optimization, process controls, insulation improvement

- Recycle waste heat within the process

- e.g., preheating combustion air, make-up air, fuel, and charging materials

- Recover waste heat to produce steam

Recover - Recover energy through waste heat to power generation

Recovering waste heat to produce steam is very common, as steam is a necessity for a number of manufacturing processes. A Heat Recovery Steam Generator (HRSG) is inexpensive and can be configured relatively easily with the process demands and existing operations. The properties of the waste heat, such as the temperature, volume, the availability of the waste heat, presence of any particulates in the waste heat, and chemical composition of the waste heat (such as corrosive gas compounds, condensable vapors, and combustible gases) are important when considering recovering waste heat for steam generation (Thekdi, 2011).

In addition, electricity can be produced from waste heat, through "waste heat to power generation" arrangements. One of the largest advantages of waste heat to power generation is that it produces a high quality energy product - electricity. Electricity can be used in all processes and different locations. However, waste heat to power generation is normally capital-intensive and much less energy efficient. Therefore, it is suggested that only when there are no other possible ways to utilize waste heat as heat (preheating, producing steam and/or hot water), waste heat to power generation can be considered.

The principle of "Reduce, Recycle, and Recover" is important for managing waste heat. This principle can improve the economic viability of waste heat utilization projects and tailor the 
potential of waste heat to its best use. It serves as the foundation for waste heat potential

\section{Waste Heat Potential Analysis}

302 This analysis focused on three industrial sectors in China: cement, iron and steel, and glass. These three sectors were chosen because of their characteristics (see Table 3). Generally, sectors with high energy consumption have higher exhaust gas temperatures and, as a result, have more potential for capturing the waste heat. The complexity of the manufacturing process used within the sector may hinder the adoption of waste heat to power generation, so the current utilization rate of waste heat recovery plays an important role in determining the potential as well. Certainly, there are other manufacturing sectors such as chemicals, pulp and paper, and non-ferrous metals that could also be analyzed. However, this study focused on the cement, iron and steel, and flat glass sectors, each representing different waste heat utilization conditions.

Table 3. Characterization of Selected Sectors

\begin{tabular}{lcccc}
\hline Sector & $\begin{array}{c}\text { Sectoral Total } \\
\text { Energy Use }\end{array}$ & $\begin{array}{c}\text { Exhaust Gas } \\
\text { Temperature }\end{array}$ & $\begin{array}{c}\text { Process } \\
\text { Complexity }\end{array}$ & $\begin{array}{c}\text { Heat Recovery } \\
\text { Utilization Rate }\end{array}$ \\
\hline Cement & High & High & Low & High \\
Iron and Steel & High & Medium-High & High & Low \\
Glass & Medium & Medium & Low & Low \\
\hline
\end{tabular}

314

The purposes of this analysis are to determine the technical potential of waste heat as well as to identify industry characteristics for implementation of easily-adopted and cross-sector waste heat to power generation technologies in China. Therefore, this analysis focused on already commercialized technologies, such as the Steam Rankine Cycle and the Organic Rankine Cycle, which can be applied to a number of energy systems and sectors. In other words, power generation technologies that are tailored to certain manufacturing processes such as Top Pressure Recovery Turbines for blast furnaces in iron-making, technologies that have not achieved wide adoption such as the Kalina Cycle or supercritical $\mathrm{CO}_{2}$ cycle, or other emerging technologies such as thermoelectric generation and piezoelectric power generation, are not within the scope of this analysis.

The sections below discuss the analysis and findings for the three studied sectors, with a focus on data and assumptions used in the cement sector analysis. Details of data and assumptions used in the other two sectors can be found in the author's thesis (Lu, 2015).

\subsection{Cement sector}

\subsubsection{Industry background} China has been the world's largest cement producer since 1986 (LBNL and CBMA, 2012). In 2012 , China produced 2.2 billion metric tons of cement, represented $60 \%$ of global production 
(USGS, 2014a). The cement industry is the third largest energy-consuming manufacturing sector in China, representing $12 \%$ of China's total manufacturing energy use, or about $5 \%$ of China's total energy use in 2012 (NBS, 2013a). In addition, China's cement industry is very fuelintensive. From 2008 to 2012, about 90\% of energy input was fuel while around 10\% was from electricity (CCA, 2008-2014). Coal is the predominant fuel source in the Chinese cement industry, contributing around $97 \%$ of the fuel input.

There are two main sources of waste heat in cement manufacturing. The first one is the exhaust gas from the cement kiln, where clinker calcination takes place. The clinker making process is the most energy-intensive process in which the kiln feed is combusted at a high temperature, about $982^{\circ} \mathrm{C}\left(1,800^{\circ} \mathrm{F}\right)$ in the calcination stage and the oxides react to form clinker at a temperature of $1,510^{\circ} \mathrm{C}\left(2,750^{\circ} \mathrm{F}\right)$ (US EPA, 1995). The exhaust temperature from the cement kiln can vary from $449^{\circ} \mathrm{C}\left(840^{\circ} \mathrm{F}\right)$ to $204^{\circ} \mathrm{C}\left(400^{\circ} \mathrm{F}\right)$, depending on the waste heat recovery technologies used (US DOE, 2008). The second main source of waste heat is from the clinker cooler. In this step, red-hot clinker is discharged from the kiln to the clinker cooler. It is then rapidly cooled from $1,093^{\circ} \mathrm{C}$ to less than $93^{\circ} \mathrm{C}\left(2,000^{\circ} \mathrm{F}\right.$ to $\left.200^{\circ} \mathrm{F}\right)$ by ambient air. The heated air not only cools the clinker but also recovers portions of the heat.

Energy contained in the exhaust gases from the kiln and the clinker cooler can be recovered and reused to provide valuable energy services, such as use for drying and preheating the kiln feed in preheaters, preheating secondary air in the kiln's combustion system, or preheating tertiary air for the precalciner. This analysis focuses on the waste heat from the kiln exhaust and the clinker cooler.

\subsubsection{Data and key assumptions} As of 2012, a large majority of China's cement kilns are dry process rotary kilns, referred to as "New Suspension Preheater" (NSP) kilns in China. This technology includes rotary kilns with preheaters only, and rotary kilns with preheaters and precalciners. In 2012, NSP kilns represented $92 \%$ of total clinker production in China (CCA, 2014). As shown Table 4, about $37 \%$ of clinker was produced from NSP kilns larger than 4,000 metric tons of clinker per day (tpd). NSPs that produce $1,000-2,000$ tpd accounted for another $36 \%$. Small NSP kilns $(<1,000 \mathrm{tpd})$ contributed to $15 \%$ of total clinker production.

Table 4. Clinker Production by Kiln Size in China (2012)

\begin{tabular}{|l|c|c|}
\hline \multirow{2}{*}{ Cement Sector } & $\begin{array}{c}\text { \% of total clinker } \\
\text { production }\end{array}$ & $\begin{array}{c}\text { Clinker Production } \\
\text { (Mt) }\end{array}$ \\
\cline { 2 - 3 } & $100 \%$ & 1,328 \\
\hline NSP $<1,000$ tpd & $15 \%$ & 194 \\
\hline NSP $1,000-2,000$ tpd & $36 \%$ & 473 \\
\hline NSP $2,000-4,000$ tpd & $5 \%$ & 69 \\
\hline NSP $>4,000$ tpd & $37 \%$ & 485 \\
\hline Non-NSP & $8 \%$ & 106 \\
\hline
\end{tabular}


The General Administration of Quality Supervision, Inspection and Quarantine of China (AQSIQ) and the Standardization Administration of China (SAC) publish minimum energy performance standards (MEPS) for industrial products, which are updated periodically. The latest MEPS standard (GB 16780-2012) for cement was published in December 31 $1^{\text {st }}, 2012$ and took effective on October $1^{\text {st }}, 2013$ (AQSIQ and SAC, 2012). This standard prescribed minimum energy performance levels (i.e., the maximum amount of energy could be used to produce one unit of production) for existing cement plants, minimum energy performance levels for newly constructed cement plants, as well as advanced international values. The minimum energy performance levels are provided for NSP kilns and broken down by kiln size.

As a mandatory standard, all existing cement plants are required to meet the minimum performance requirements, at least in theory. This study recognizes that the compliance rate of the MEPS standard may not be $100 \%$; however, this study also found some cement plants (typically large and newer plants) report and/or have lower energy intensity levels than required by the MEPS. For these reasons, this study used minimum energy performance levels of the existing cement plants in the MEPS standard as an average energy intensity level for existing NSP kilns in 2012 (see Table 5). The energy intensities of non-NSP kilns (such as wet kilns and dry hollow kilns) used in this study are based on the investigation conducted by Lawrence Berkeley National Laboratory and the World Bank in 16 cement plants in Shandong Province, China in 2008 (Price et al., 2009).

Table 5. Energy Intensity of Cement Production by Size in China

\begin{tabular}{|l|c|c|}
\hline \multirow{2}{*}{ Kiln type/ size } & $\begin{array}{c}\text { Fuel Intensity } \\
\text { (kgce/t clinker) }\end{array}$ & $\begin{array}{c}\text { Electricity Intensity } \\
\text { (kWh/t cement) }\end{array}$ \\
\hline NSP $<1,000$ tpd $^{\mathrm{a}}$ & 135 & 120 \\
\hline NSP $1,000-2,000 \mathrm{tpd}^{\mathrm{a}}$ & 130 & 115 \\
\hline $\mathrm{NSP} 2,000-4,000 \mathrm{tpd}^{\mathrm{a}}$ & 125 & 110 \\
\hline $\mathrm{NSP}>4,000 \mathrm{tpd}^{\mathrm{a}}$ & 120 & 105 \\
\hline Non-NSP & 141 & 119 \\
\hline
\end{tabular}

Source: a - AQSIQ and SAC, 2012; b-Price et al., 2009.

Note: NSP kiln intensity values based on the Chinese MEPS; non-NSP values based on field surveys.

Exhaust gas temperatures may vary, depending on a number of factors, such as types of kiln used, combustion controls, handling of materials, and the length of the kiln. This analysis assumed two exhaust temperatures for NSP kilns and non-NSP kilns, respectively. Based on expert interviews of international and Chinese experts in the field and literature research, it is assumed that the exhaust gas temperature for NSP kilns is around $338^{\circ} \mathrm{C}\left(640^{\circ} \mathrm{F}\right)$ and the exhaust gas temperature for non-NSP kilns is approximately $490^{\circ} \mathrm{C}\left(840^{\circ} \mathrm{F}\right)$ (US DOE, 2008; ERI, 2011; Harrell, 2014). Table 6 shows the estimated energy use and typical exhaust gas temperature by cement kiln. 
Table 6. Fuel Use and Exhaust Temperature by Kiln Size (2012)

\begin{tabular}{|l|c|c|c|}
\hline \multirow{2}{*}{ Cement Sector } & \multirow{2}{*}{ Fuel Use } & \multicolumn{2}{|c|}{$\begin{array}{c}\text { Typical Average Exhaust } \\
\text { Temperature }\end{array}$} \\
\cline { 3 - 4 } & \multirow{2}{*}{ (Mtce/yr) } & ${ }^{\circ} \mathbf{F}$ & ${ }^{\circ} \mathbf{C}$ \\
\cline { 2 - 4 } & 170 & & \\
\hline NSP $<1,000$ tpd & 26 & 640 & 338 \\
\hline NSP 1,000-2,000 tpd & 62 & 640 & 338 \\
\hline NSP 2,000-4,000 tpd & 9 & 640 & 338 \\
\hline NSP $>4,000$ tpd & 58 & 640 & 338 \\
\hline Non-NSP & 15 & 840 & 449 \\
\hline
\end{tabular}

\subsubsection{Results}

Based on the 2012 historical production data, more than a quarter (26\%) of the fuel used in China's cement sector is released as waste heat and could be captured, at least theoretically. Medium to high temperature waste heat $\left(>150^{\circ} \mathrm{C}\left[300^{\circ} \mathrm{F}\right]\right)$ represents about $13 \%$ of the fuel input, while low-temperature waste heat (below $150^{\circ} \mathrm{C}\left[300^{\circ} \mathrm{F}\right]$ ) accounts for nearly another $13 \%$, as illustrated in Figure 2.

410
Waste Heat Potential of Cement Sector in China (2012)

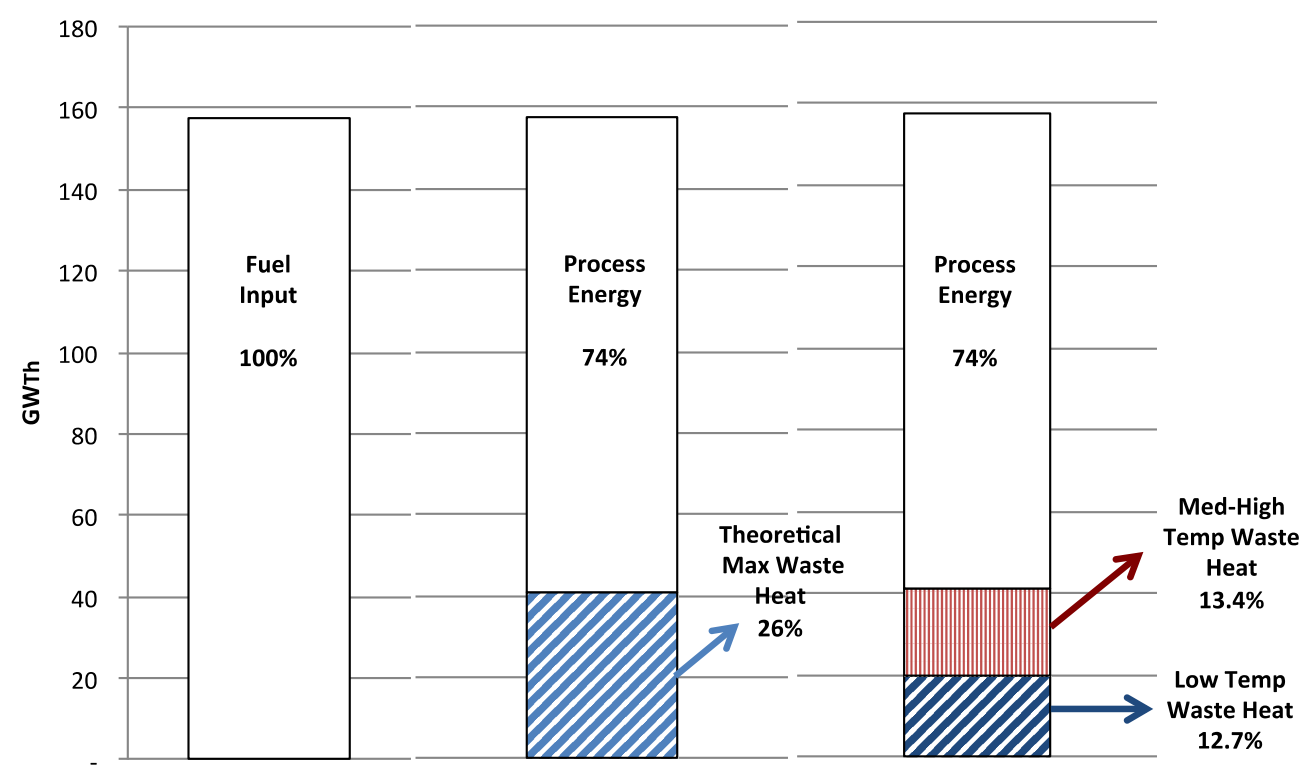

Figure 2. Waste Heat Potential of the Cement Sector in China (2012)

The results showed that China's cement industry has a theoretical maximum waste heat potential of $41 \mathrm{GW}_{\mathrm{Th}}$. About $10 \%$ of this potential, or $4 \mathrm{GW}_{\mathrm{e}}$, can be converted to produce power, using today's commercialized technologies and real-world power generation efficiency. However, power generation potential could be doubled to $10 \mathrm{GW}_{\mathrm{e}}$ if the efficiency can be improved to be close to the Carnot Efficiency through advances in technologies, materials, and chemical properties. The theoretical maximum power generation potential could be increased 
419 to more than $20 \mathrm{GW}_{\mathrm{e}}$ if both the Carnot Efficiency and the maximum heat recovery are 420 achieved. The remaining $49 \%$ of the waste heat potential is in the form of low-temperature 421 (near ambient) waste heat (Figure 3).

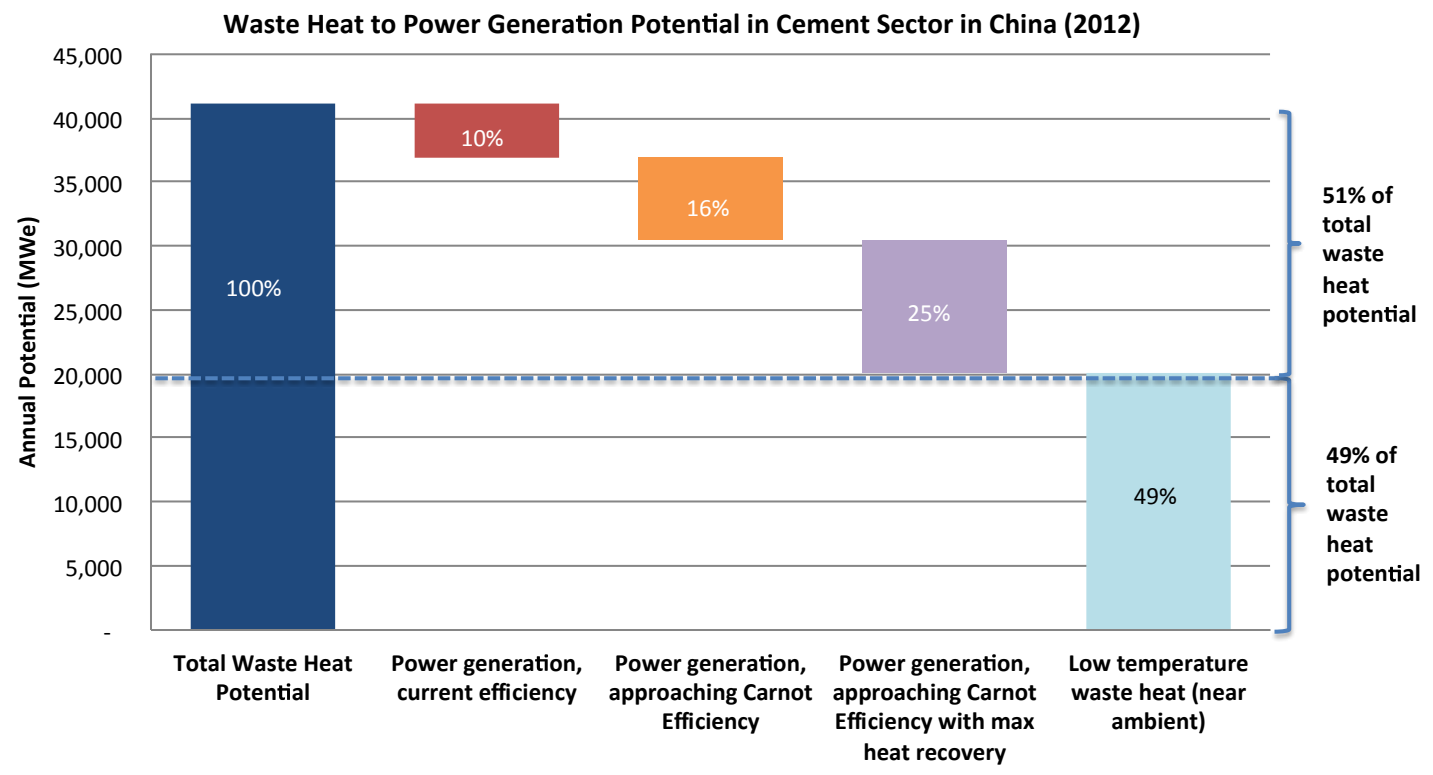

Figure 3. Waste Heat to Power Generation Potential of the Cement Sector in China (2012)

China has been promoting waste heat to power generation in the cement sector since the $11^{\text {th }}$ Five-Year Plan (2005-2010) through its "Ten Key Projects", which includes "waste heat and waste heat utilization projects" as one of the ten government promoted energy-saving projects. By the end of 2010, 55\% of China's NSP kilns were equipped with waste heat to power generation, according to the central government's planning report (MIIT, 2011b). It is reported that as of 2012, the penetration of waste heat to power generation reached to more than $70 \%$ (China Environment News, 2013). The current target for waste heat to power penetration in the cement sector is $75 \%$ by the end of the $12^{\text {th }}$ Five-Year (2011-2015) (MIIT, 2011b). This means the currently available, untapped potential is much less, about $1 \mathrm{GW}_{\mathrm{e}}$, of practical electricity generation potential. However, the widespread adoption of waste heat to power technologies in the cement sector not only demonstrates the viability of the technology but also indicates the scalability of the application. Energy-intensive sectors that are similar to the cement industry may be able to replicate the successful example of adopting this energy-recovery approach. Table 7 summarizes the results of waste heat potential in the cement sector. 


\begin{tabular}{|c|c|c|c|c|c|c|}
\hline \multirow{4}{*}{ Cement Sector } & \multicolumn{2}{|c|}{$\begin{array}{l}\text { Thermal Energy Potential } \\
\text { (in the form of heat) }\end{array}$} & \multicolumn{4}{|c|}{$\begin{array}{l}\text { Electricity Potential } \\
\text { (in the form of power) }\end{array}$} \\
\hline & $\begin{array}{l}\text { Theoretical Waste } \\
\text { Heat Potential }\end{array}$ & $\begin{array}{c}\text { Practical Waste Heat } \\
\text { Potential }\end{array}$ & $\begin{array}{c}\text { Theoretical Power } \\
\text { Generation Potential }\end{array}$ & $\begin{array}{c}\text { Practical Power } \\
\text { Generation Potential }\end{array}$ & $\begin{array}{c}\text { Practical Power } \\
\text { Generation Potential }\end{array}$ & $\begin{array}{l}\text { Untapped Power } \\
\text { Generation Potential }\end{array}$ \\
\hline & {$\left[T_{\text {ref }}=25^{\circ} \mathrm{C}\left(77^{\circ} \mathrm{F}\right)\right]$} & {$\left[T_{\text {ref }}=150^{\circ} \mathrm{C}\left(300^{\circ} \mathrm{F}\right)\right]$} & $\begin{array}{c}\text { [Theoretical Thermal } \\
\text { Potential } \times \text { Carnot } \\
\text { Efficiency] }\end{array}$ & $\begin{array}{c}\text { [Practical Thermal } \\
\text { Potential } \times \text { Carnot } \\
\text { Efficiency] }\end{array}$ & $\begin{array}{c}\text { [Practical Thermal } \\
\text { Potential } \times \text { Practical } \\
\text { Efficiency] }\end{array}$ & $\begin{array}{c}\text { [Practical Thermal } \\
\text { Potential } \times \text { Practical } \\
\text { Efficiency } \times \\
\text { (1-Penetration Rate)] }\end{array}$ \\
\hline & $\mathbf{M W}_{\mathrm{Th}}$ & $\mathbf{M W}_{\text {Th }}$ & $\mathrm{MW}_{\mathrm{e}}$ & $\mathrm{MW}_{\mathrm{e}}$ & $\mathrm{MW}_{\mathrm{e}}$ & $\mathrm{MW}_{\mathrm{e}}$ \\
\hline Potential & 41,117 & 21,108 & 21,037 & 10,654 & 4,222 & 1,266 \\
\hline
\end{tabular}




\subsection{Iron and steel sector}

\subsubsection{Industry background} China is the world's largest iron and steel producer. In 2012, China produced $60 \%$ of global pig iron and $46 \%$ of global crude steel (USGS, 2014b). Iron and steel production is one of the largest energy sectors in China, with energy consumption accounting for 10-15\% of total energy use and $15-20 \%$ of total industrial energy use (Ma et al., 2012). More than $96 \%$ of energy input in China's iron and steel sector comes from fuel, including coke, washed coal, and raw coal. The energy efficiency of China's iron and steel sector has improved over the last ten years while production has increased at a rapid rate, but the specific energy consumption of iron and steel sector is still $20 \%$ higher than international advanced levels (Ma et al., 2012).

China's current steel-making capacity has exceeded 1 billion metric tons, with a utilization rate of 70\% in 2013 (MIIT, 2014). Overcapacity directly affects the prices of products as production has increased much faster than demand. This has led to low profit margins for small steel producers domestically and low-cost and low-quality products in the global steel market. Compared to domestic steel consumption, the net export of steel is still small (about $6 \%$ of total finished steel production was exported in 2012). However, given China's large production volume, a small percentage translates into a large absolute number, e.g., China's steel export was about 56 million metric tons in 2012, which is higher than the total steel production of Germany that year. Product quality is a weakness of China's iron and steel sector. According to the Chinese Ministry of Industry and Information Technology (MIIT), only 30\% of the Chinese steel production achieved international advanced quality levels (MIIT, 2011c).

\subsubsection{Data and key assumptions}

464 Specific energy intensities by process and production data for China's iron and steel sector in 2012 were obtained from the 2013 China Iron and Steel Yearbook (Editorial Board of China Steel Yearbook, 2013). The China Energy Statistical Yearbook (NBS, 2013a) reported the recovered amount of coke oven gas, blast furnace gas, and basic oxygen furnace gas. In addition, this analysis took into account the current adoption rates of waste heat recovery technologies in this sector. Based on the estimated implementation rates and typical energy recovery rates, this analysis estimated the amount of recovered energy in Coke Dry Quenching (CDQ), sintering machines, Top Pressure Recovery Turbine (TRT), recovered steam from basic oxygen furnace (BOF), as well as waste heat recovery in electric arc furnace (EAF). The shares of electricity in each process are based on reported data from the China Iron and Steel Association (Huang, 2013). Table 8 presents the estimated energy use by process in this sector.

In 2012, the blast furnace accounted for more than $60 \%$ of the total energy use in China's iron and steel sector (Table 8). The analysis focused on easily adopted and cross-sector waste heat to power generation technologies. Thus, the analysis further identified waste heat from the blast stove of the blast furnace process as the potential area to recover waste heat to produce 481 power. 
Table 8. Energy Use of China's Iron and Steel Sector by Process (2012)

\begin{tabular}{|c|c|c|c|c|c|c|c|}
\hline Iron and Steel & $\begin{array}{c}\text { Reported Energy } \\
\text { Intensity }\end{array}$ & Production & $\begin{array}{c}\text { Final Energy } \\
\text { Use }\end{array}$ & $\begin{array}{c}\text { Recovered } \\
\text { Energy }\end{array}$ & $\begin{array}{c}\text { Total Energy } \\
\text { Input }\end{array}$ & $\begin{array}{c}\text { Share of } \\
\text { Electricity }\end{array}$ & $\begin{array}{c}\text { Total Fuel } \\
\text { Use }\end{array}$ \\
\hline Making Process & kgce/t & Mt & Mtce & Mtce & Mtce & $\%$ & Mtce \\
\hline Coke ovens & 105 & 442 & 46 & 23 & 70 & $1 \%$ & 69 \\
\hline Sintering & 50 & 810 & 41 & 2 & 42 & $10 \%$ & 38 \\
\hline Pelletizing & 29 & 136 & 4 & & & $10 \%$ & 4 \\
\hline Blast Furnace & 402 & 670 & 270 & 15 & 285 & $1 \%$ & 282 \\
\hline Basic Oxygen Furnace & -6 & 666 & -4 & 7 & 3 & $15 \%$ & 3 \\
\hline Electric Arc Furnace & 67 & 65 & 4 & 1 & 5 & $40 \%$ & 3 \\
\hline $\begin{array}{l}\text { Continuous Casting, } \\
\text { Rolling, and Refining }\end{array}$ & $\mathrm{N} / \mathrm{A}$ & N/A & 46 & $\mathrm{~N} / \mathrm{A}$ & 46 & $15 \%$ & 39 \\
\hline Total & 604 & 731 & 407 & 48 & 455 & N/A & 437 \\
\hline
\end{tabular}

483 Note: "Recovered Energy" refers to energy that is recovered and reused in the processes.

484 Source: Editorial Board of China Steel Yearbook, 2013; Huang, 2013; NBS, 2013a. 


\subsubsection{Results}

486 The blast stove is used to preheat air for use in the blast furnace for iron making. The potential for recovering waste heat from the blast stove exhaust of the blast furnace is relatively small compared to the total energy input of the blast furnace. This is mostly due to the fact that there are other waste heat recovery opportunities, such as recovering blast furnace gas and recovering waste pressure from the blast furnace.

The analysis showed that a maximum technical waste heat potential of $2.9 \mathrm{GW}_{\mathrm{Th}}$ is available, with a practical waste heat potential of $1 \mathrm{GW}_{\mathrm{Th}}$. The waste heat to power generation potential of the blast stove exhaust is relatively low. As illustrated in Figure 4, the practical power generation potential is about $7 \%$ of the total waste heat potential, about $215 \mathrm{MW}_{\mathrm{e}}$. If the energy efficiency of power generation equipment could be improved to approach the Carnot Efficiency, electricity production could be doubled. If the maximum heat recovery could be achieved while power equipment efficiency approached the Carnot Efficiency, a maximum of $40 \%$ of waste heat potential could be converted to power. However, even with all the potential technical improvements, at least $60 \%$ of the waste heat potential would remain as lowtemperature (near ambient) heat.

502

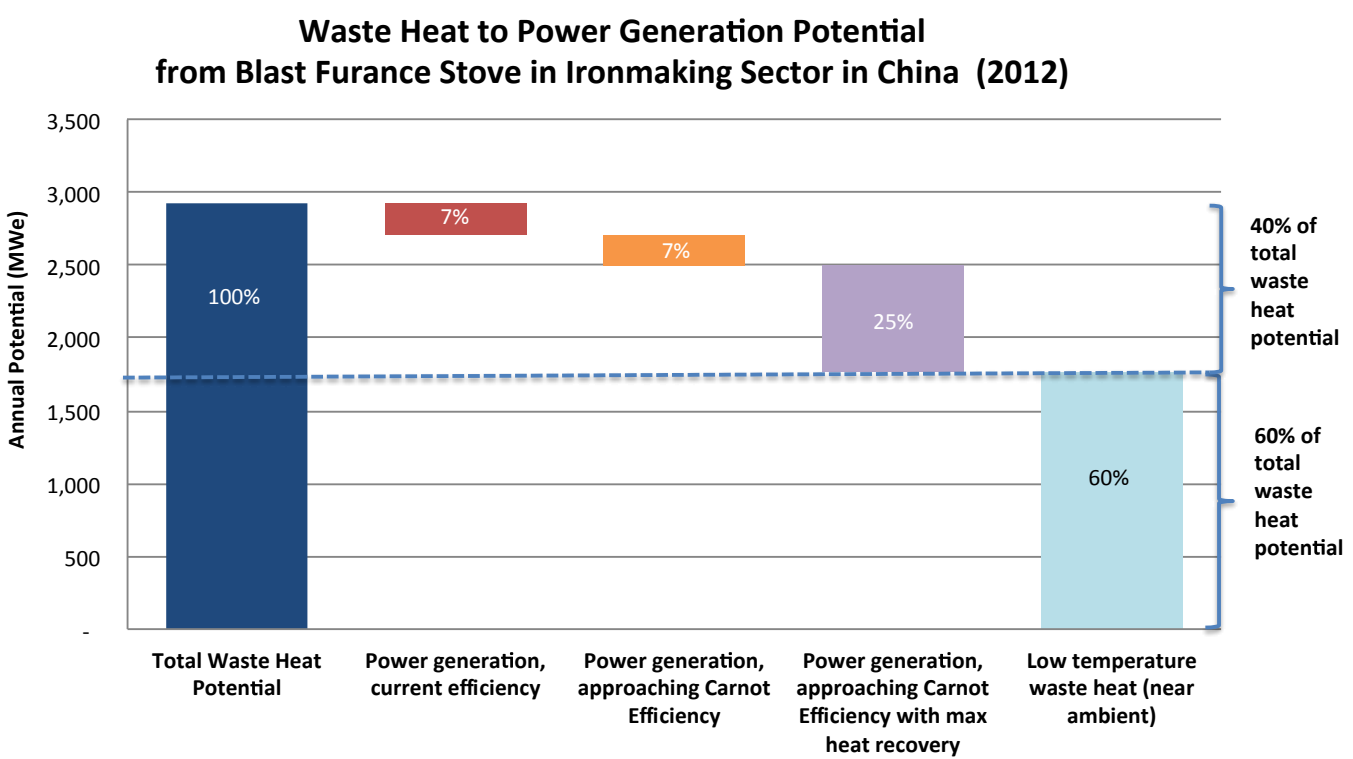

Recovered energy from blast stove exhaust can be used to preheat combustion air and fuel in the blast stoves. In China, this method has not been widely implemented and it is estimated that the current penetration level is about 5\% (Huang, 2013). points. First, waste heat to power generation is a valuable option and could be developed in the future. Second, other ways to recycle and recover waste heat, such as Coke Dry Quenching 
513 (CDQ), Top Pressure Recovery Turbine (TRT), and recovering sensible heat from slag are equally 514 important as waste heat to power generation. Lastly, the potential of waste heat to power generation may not be as large as waste heat recycling and reuse. In other words, this analysis found that the iron and steel sector has the potential to develop waste heat to power generation, but the industry characteristics are more suitable or favorable for utilization of

518 waste heat as thermal energy.

\subsection{Glass sector}

\subsubsection{Industry background}

521 Flat glass is the main glass product in China, representing about $70 \%$ of total glass production nationally. As of 2011, China produced about 740 billion weight cases of flat glass (equivalent to 37 million metric tons), and 14 million metric tons of container glass (Sina News, 2012). From 2000 to 2012, China's flat glass production grew at an average rate of $13 \%$ per year (NBS, 2013b).

The dominance of flat glass in China is quite different from developed countries. In the U.S., container glass is the largest glass industry segment, accounting for $50 \%$ of total glass production. In the European Union (EU-25), container glass represented $53 \%$ of total production in 2005. Domestically, China's glass manufacturers are quite dispersed but a majority of companies use the floating process to produce flat glass. By 2010, China had around 280 flat glass production lines, and about 240 of them were floating glass processes (ERI, 2011). In comparison, EU-27 countries have less than 60 flat glass production lines. Globally, although China accounted more than half of the world's flat glass production in 2011, none of the Chinese glass companies are among the top four glass companies (European Commission, 2013a). It is estimated that about $37 \%$ of the global flat glass production is low quality and mainly comes from China (IIP, 2014).

The glass sector in China consumed about 12 Mtce in 2012, accounting for about $1 \%$ of total industrial energy use, or $0.4 \%$ of China's national energy consumption (NBS, 2013a). The flat glass industry in China mainly relies on coal (63\%) and fuel oil as energy inputs (Wang, 2011). As of 2006, electricity consumption accounted for $5 \%$ of the total energy consumption in this sector (China Economic Net, 2007). A typical energy distribution of a float glass process shows that the melting and refining process consumes about $83 \%$ of total energy inputs (Worrell et al., 2008; European Commission, 2013a). The main source of waste heat in the float glass process is the exhaust from the glass furnace in the melting and refining process.

548 This analysis categorized the sizes of the glass furnaces into those that are smaller than or equal 549 to 500 metric tons per day (tpd), those that are larger than 500 but smaller than 800 metric 550 tons per day, and furnaces larger than or equal to 800 metric tons per day. The General 551 Administration of Quality Supervision, Inspection and Quarantine of China (AQSIQ) and the 552 Standardization Administration of China (SAC) published two minimum energy performance 553 standards (MEPS) for glass furnaces in 2008 and 2013. Considering 2012 is the base year of this 
554 analysis, the average values of the energy intensity between the two standards are used for this

555 study (Table 9).

Table 9. Energy Intensity of Flat Glass Production in China (2012)

\begin{tabular}{|l|c|c|c|}
\hline \multirow{2}{*}{ Furnace size } & Energy Intensity & Energy Intensity & Fuel Intensity \\
\cline { 2 - 4 } & (kgce/weight case) & (kgce/kg) & (kJ/kg) \\
\hline$\leq 500 \mathrm{tpd}$ & 14 & 0.28 & 6,700 \\
\hline $500 \mathrm{tpd}-800 \mathrm{tpd}$ & 13.5 & 0.27 & 6,400 \\
\hline$>800 \mathrm{tpd}$ & 12 & 0.24 & 5,650 \\
\hline
\end{tabular}

Source: based on AQSIQ and SAC, 2008 and AQSIQ and SAC, 2013.

China's National Bureau of Statistics (NBS) reports flat glass production annually. However,

561 production by furnace sizes is not available. This study assumed that $5 \%$ of the production was produced by smaller furnaces ( $\leq 500 \mathrm{tpd}$ ), given the Chinese government's push to close down

563 small facilities and phase out small and old production units. Based on the $12^{\text {th }}$ Five-Year Plan

564 for flat glass development in China, this analysis assumed 25\% of flat glass production in 2012

565 came from furnaces larger than or equal to $800 \mathrm{tpd}$ (MIIT, 2011a). Table 10 shows the production of flat glass by furnace sizes in 2012.

568 Table 10. Flat Glass Production by Furnace Size in China (2012)

\begin{tabular}{|l|c|c|}
\hline \multirow{2}{*}{ Flat Glass Sector } & Production & Share of Total Production \\
\hline Sector-wide & Mt & $\%$ \\
\hline$\leq 500 \mathrm{tpd}$ & 40 & $100 \%$ \\
\hline $500 \mathrm{tpd}-800 \mathrm{tpd}$ & 2 & $5 \%$ \\
\hline$\geq 800 \mathrm{tpd}$ & 28 & $70 \%$ \\
\hline
\end{tabular}

569

570

571

572

573

574

575

576

577

578

579

580

581

Source: NBS, 2013b; MIIT, 2011a; and author calculations.

Energy use by manufacturing subsector is only available at an aggregated level in China. The energy use in the glass sector is reported with cement manufacturing, ceramic manufacturing, and other building materials under the "Non-Metallic Mineral Products". NBS reported that in 2012 the non-metallic mineral products sector consumed about 241 Mtce. Based on China's goals for the flat glass industry development, it is assumed the flat glass industry in China accounted for about $5 \%$ of energy use in the manufacturing of non-metallic mineral products, with a total energy use close to 12 Mtce in 2012 (Table 11). The result is in agreement with China's Implementation Guide on the Energy Management System of Flat Glass Industry (CNIS, 2013), and the MEPS standards (AQSIQ and SAC, 2008; AQSIQ and SAC, 2013).

Table 11. Energy Use by Furnace Size in China's Glass Sector (2012)

\begin{tabular}{|c|c|}
\hline \multirow{2}{*}{ Flat Glass Sector } & Total Energy Use \\
\cline { 2 - 2 } Sector-wide & Mtce/year \\
\hline$\leq 500$ tpd & 11.9 \\
\hline
\end{tabular}




\begin{tabular}{|l|c|}
\cline { 2 - 2 } $500 \mathrm{tpd}-800 \mathrm{tpd}$ & 8.9 \\
\hline$\geq 800 \mathrm{tpd}$ & 2.4 \\
\hline
\end{tabular}

Exhaust temperature varies depending on technologies used. As shown in Table 12, an oxy-fuel furnace (i.e., use pure oxygen as combustion air) has the highest exhaust temperature. This is because it can increase the combustion temperature to a much higher degree by using pure oxygen. However, this does not directly translate into higher waste heat potential, as the mass of exhaust is reduced (saving energy as well). Regenerative and electric-boosted furnaces have the lowest exhaust gas temperature, due to high energy utilization rates (for regenerative furnaces) and high energy conversion efficiency (for electric-boosted furnaces). A recuperative furnace recovers a portion of the waste heat potential through a heat exchanger, but its exhaust temperature is still relatively high.

Table 12. Typical Exhaust Temperatures by Furnace Type in Glass Sector

\begin{tabular}{|l|c|c|}
\hline \multirow{2}{*}{ Furnace Type } & \multicolumn{2}{|c|}{ Typical Exhaust Temperature } \\
\cline { 2 - 3 } & ${ }^{\circ} \mathbf{F}$ & ${ }^{\circ} \mathbf{C}$ \\
\hline Regenerative & 800 & 427 \\
\hline Electric-Boosted & 800 & 427 \\
\hline Recuperative & 1,800 & 982 \\
\hline Oxy-Fuel & 2,600 & 1,427 \\
\hline
\end{tabular}

Source: US DOE, 2008.

China currently has very few oxy-fuel furnaces and the share of electric-boosted furnaces is still low even though it is increasing. The main types of furnaces in China are regenerative and recuperative. China has been implementing a national policy to close down small plants and phase out obsolete capacity in Chinese energy-intensive industries since 2005. Now the existing facilities are relatively new, have newer designs, and employ relatively larger and more efficient furnaces. In addition, considering that many glass facilities are already recovering a portion of the waste heat potential from the exhaust to preheat combustion air and/or the charging materials, this analysis assumed the typical average exhaust temperature of the Chinese glass furnaces to be around $427^{\circ} \mathrm{C}\left(800^{\circ} \mathrm{F}\right)$. This value is the low-end estimate compared to the reported exhaust temperature in China, which is in the range of $400^{\circ} \mathrm{C}$ to $600^{\circ} \mathrm{C}\left(752^{\circ} \mathrm{F}\right.$ to $\left.1,112^{\circ} \mathrm{F}\right)(\mathrm{ERI}, 2011)$. This indicates that the total estimated waste heat potential of the Chinese glass sector in this analysis may be lower than the actual potential.

There is very limited reporting on the current penetration of waste heat to power generation technologies in China's flat glass sector. However, based on government think tank reports and the Chinese government's $12^{\text {th }}$ Five-Year Plan for the glass sector, the Ministry of Industry and Information Technology (MIIT) estimated that there are 20 units of waste heat to power generation in the glass sector (MIIT, 2011a). The government think tank Energy Research Institute (ERI) reported that there are around 240 production lines in flat glass sector (ERI, generation technologies in the flat glass sector is about $8 \%$. 


\subsubsection{Results}

619 The theoretical maximum waste heat technical potential in China's flat glass industry is about

$6201.8 \mathrm{GW}_{\text {Th }}$ based on 2012 data. The practical waste heat potential is determined to be around 1 $621 \mathrm{GW}_{\mathrm{Th}}$. This shows the total waste heat potential is about $16 \%$ of the industry's fuel input. The 622 practical waste heat potential is about $9 \%$ of the total fuel input (Figure 5).

Waste Heat Potential of Glass Sector in China (2012)

623

624

625

626

627

628

629

630

631

632

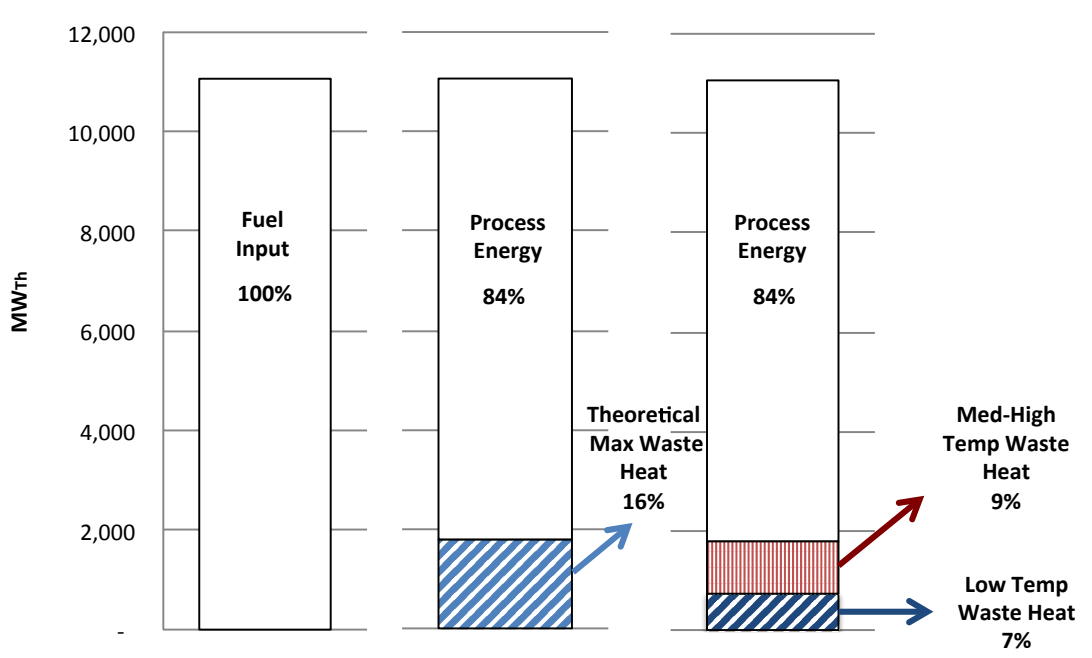

\section{Figure 5. Waste Heat Potential in the Glass Sector in China (2012)}

The practical power generation potential for China's flat glass sector is about $207 \mathrm{MW}$. This considers the real world efficiency of converting thermal energy to power, as well as the practical amount of thermal energy that could be recovered. This represents about $13 \%$ of the total theoretical maximum waste heat potential. Power generation potential could be more than doubled if power equipment efficiency could approach to the Carnot Efficiency. If waste heat recovery could be maximized as well, a total of $57 \%$ of the waste heat could be converted to power (Figure 6).

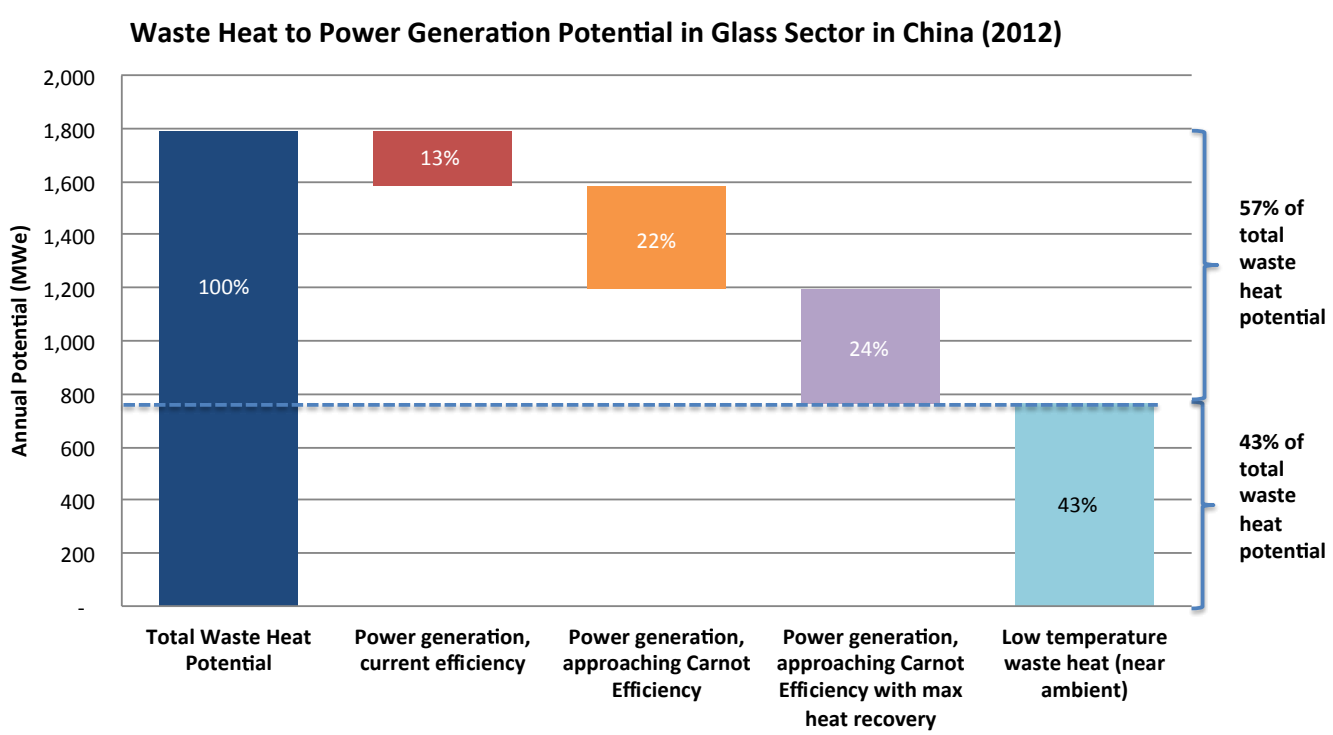


635 Given that the current penetration of waste heat to power generation in China's flat glass 636 sector is estimated to be around $8 \%$, this indicates that an untapped practical power generation potential of $190 \mathrm{MW}_{\mathrm{e}}$ is available. This may be an underestimate, as this analysis uses conservative assumptions related to exhaust gas temperatures and waste heat to power efficiency. However, this provides a lower bound of the actual potential in the flat glass

640 industry.

642 The identified technical potential of waste heat to power generation of the studied sectors is 643 summarized in Table 13. The analysis found that the cement sector has significant waste heat 644 to power generation potential in China. Even with a high penetration level of waste heat to 645 power technologies, the cement sector still has the highest untapped power generation 646 potential compared to other sectors studied in the analysis. The technical characteristics of the 647 cement sector can be used as a helpful case to identify favorable sectors for adopting waste 648 heat to power generation technologies.

The iron and steel sector in China has a significant energy profile. By focusing on the largest 651 energy-using process of the sector (blast furnace) this analysis identified more waste heat to 652 power generation potential than the whole sector of the glass industry in China. However, the 653 process and nature of the iron and steel industry is complex and requires steam for process use. 654 The process delivers various products and often releases waste heat with contaminants. This is 655 an industry that is best for optimizing waste heat potential as thermal energy, through waste 656 heat reduction, reuse, and recycling. Pursuing waste heat to power generation is possible; 657 however, the potential is much smaller than thermal waste heat utilization. Technologies for 658 waste heat to power generation in the iron and steel sector could be further developed and 659 implemented. However, the possibility of applying technologies that are tailored to the iron and 660 steel sector to other sectors seems to be limited and needs to be further researched.

\section{1}

662 Table 13. Waste Heat to Power Generation Potential in Selected Sectors in China (2012)

\begin{tabular}{|c|c|c|c|c|c|}
\hline & $\begin{array}{l}\text { Untapped Power } \\
\text { Generation } \\
\text { Potential } \\
\text { [Practical Thermal } \\
\text { Potential } \times \text { Practical } \\
\text { Efficiency } \times \\
\text { (1-Penetration } \\
\text { Rate)] }\end{array}$ & $\begin{array}{c}\text { Practical Power } \\
\text { Generation } \\
\text { Potential } \\
\\
\text { [Practical } \\
\text { Thermal } \\
\text { Potential } x \\
\text { Practical } \\
\text { Efficiency] }\end{array}$ & $\begin{array}{c}\text { Practical Power } \\
\text { Generation } \\
\text { Potential } \\
\\
\text { [Practical } \\
\text { Thermal } \\
\text { Potential } \times \\
\text { Carnot } \\
\text { Efficiency] }\end{array}$ & $\begin{array}{c}\text { Theoretical } \\
\text { Power } \\
\text { Generation } \\
\text { Potential } \\
\text { [Theoretical } \\
\text { Thermal Potential } \\
\times \text { Carnot } \\
\text { Efficiency] }\end{array}$ & $\begin{array}{c}\text { Waste Heat to } \\
\text { Power Generation } \\
\text { [Practical } \\
\text { Potential] }\end{array}$ \\
\hline Sector & MWe & MWe & MWe & MWe & kWh/t \\
\hline Cement & 1,266 & 4,222 & 10,654 & 21,037 & $\begin{array}{c}28 \\
\text { (per ton of clinker) }\end{array}$ \\
\hline $\begin{array}{l}\text { Iron and Steel (Blast } \\
\text { Furnace Stove*) }\end{array}$ & 205 & 215 & 594 & 1,160 & $\begin{array}{c}3 \\
\text { (per ton of iron) }\end{array}$ \\
\hline Glass & 190 & 207 & 427 & 1,027 & $\begin{array}{c}46 \\
\text { (per ton of glass) }\end{array}$ \\
\hline
\end{tabular}


665 The glass sector has a much smaller energy profile than the cement or iron and steel sectors in 666 China. However, the glass sector has the highest waste heat to power generation potential per unit of production, as shown in Table 13. Based on practical waste heat to power generation potential, the glass sector could produce $46 \mathrm{kWh}$ of electricity per metric ton of glass produced.

The glass sector shares some similar characteristics with the cement sector. Both the cement and glass sectors produce a homogenous product (clinker or glass) and both have a relatively short and simple manufacturing process, with normally one key energy-using process. Exhaust gas temperatures of these two sectors are in the medium-high range, even after waste heat has been recycled and reused as thermal energy. The exhaust gas is relatively clean, i.e., does not contain many contaminants, which makes waste heat recovery easier and less costly to implement. These characteristics are presented in Table 14. From a technical perspective and based on the successful example of the cement sector, it is possible that waste heat to power generation technologies could be implemented widely in the glass sector, especially considering the current low technology penetration rate.

\section{Table 14. Industry Characteristics for Adopting Waste Heat to Power Generation}

\begin{tabular}{ll}
\hline Category & Characteristics \\
\hline Product & Producing a homogenous product \\
Process & Relatively short and simple process \\
Temperature & Medium-high exhaust gas temperature \\
Contaminants & Fewer contaminants to avoid issues such as corrosion \\
System components & Relatively small number of system components \\
Penetration & Low penetration rate of waste heat to power technologies \\
\hline
\end{tabular}

\section{Waste Heat to Power Generation Technologies}

683 The Steam Rankine Cycle is the most commonly used technology for producing power from thermal energy in China. It is not just used for waste heat to power generation, but also widely used for power generation from coal, biomass, and nuclear. The Steam Rankine Cycle uses heat to produce steam, which then drives a turbine to produce power. The most suitable waste heat temperature range for the Steam Rankine Cycle is medium-high temperature, at about 340 to $370^{\circ} \mathrm{C}$ [650 to $700^{\circ} \mathrm{F}$ ] (US DOE, 2008). Lower temperatures are also acceptable; however, they are much less cost-effective and require bulkier equipment. Lower temperatures may also lead to potential condensation and corrosion issues. hydrochlorofluorocarbon (HCFC) or hydrocarbons, which have a lower boiling point and higher vapor pressure. Suitable waste heat temperature for the $\mathrm{ORC}$ is 150 to $300^{\circ} \mathrm{C}\left(\left[302\right.\right.$ to $\left.\left.572^{\circ} \mathrm{F}\right]\right)$. The ORC has higher efficiency compared to the Steam Rankin Cycle in using the same temperature range of waste heat.

The Kalina Cycle uses a mixture of ammonia and water as the working fluid. Different from the single working fluid cycles, the bi-working fluid's temperature increases during evaporation, 
which allows it to extract more thermal energy from the waste heat source. Its acceptable temperature ranges from $100^{\circ} \mathrm{C}$ to $450^{\circ} \mathrm{C}\left(212\right.$ to $\left.842^{\circ} \mathrm{F}\right)$. The Supercritical $\mathrm{CO}_{2}$ Power Cycle uses supercritical $\mathrm{CO}_{2}$ as working fluid. Without having a phase change (from liquid to gas), the working fluid "undergoes drastic density change over small ranges of temperature and pressure" (NETL, 2013). Table 15 summarizes the temperature ranges, working fluids, conversion efficiencies, and reported costs of these four types of commercialized waste heat to power generation technologies.

Table 15. Waste Heat to Power Generation Technologies

\begin{tabular}{|l|l|l|l|l|}
\hline & Steam Rankine & $\begin{array}{l}\text { Organic Rankine } \\
\text { (ORC) }\end{array}$ & $\begin{array}{l}\text { Kalina Cycle } \\
\text { Ammonia (NH3) } \\
\text { - Water }\end{array}$ & $\begin{array}{l}\text { Supercritical } \mathbf{C O}_{2} \\
\text { Power Cycle }\end{array}$ \\
\hline $\begin{array}{l}\text { Temperature } \\
\text { Range }\end{array}$ & $\begin{array}{l}340 \text { to } 370^{\circ} \mathrm{C} \\
{\left[644 \text { to } 700^{\circ} \mathrm{F}\right]}\end{array}$ & $\begin{array}{l}150 \text { to } 300^{\circ} \mathrm{C} \\
{\left[302 \text { to } 572^{\circ} \mathrm{F}\right]}\end{array}$ & $\begin{array}{l}100 \text { to } 450^{\circ} \mathrm{C} \\
{\left[212 \text { to } 842^{\circ} \mathrm{F}\right]}\end{array}$ & $\begin{array}{l}225 \text { to } 650^{\circ} \mathrm{C} \\
\left.\text { [437 to } 1,202^{\circ} \mathrm{F}\right]\end{array}$ \\
\hline $\begin{array}{l}\text { Working } \\
\text { Fluid }\end{array}$ & Treated water & $\begin{array}{l}\text { HCFCs or } \\
\text { hydrocarbons }\end{array}$ & $\begin{array}{l}\text { Ammonia - water } \\
\text { mixture }\end{array}$ & Carbon dioxide \\
\hline $\begin{array}{l}\text { Working } \\
\text { Aluid }\end{array}$ & $\begin{array}{l}\text { Requires } \\
\text { treatment to } \\
\text { reduce corrosion } \\
\text { and mineral } \\
\text { deposition }\end{array}$ & $\begin{array}{l}\text { Limited temperature } \\
\text { range, flammability, } \\
\text { thermally unstable at } \\
\text { higher temperature }\end{array}$ & $\begin{array}{l}\text { Limited } \\
\text { temperature } \\
\text { range, corrosive, } \\
\text { ammonia leaks }\end{array}$ & $\begin{array}{l}\text { Non-corrosive, } \\
\text { non-toxic, non- } \\
\text { flammable, } \\
\text { thermally stable }\end{array}$ \\
\hline $\begin{array}{l}\text { Conversion } \\
\text { Efficiency } \\
(\%)\end{array}$ & $10 \%$ to $20 \%$ & $8 \%$ to $12 \%$ & $8 \%$ to $15 \%$ & $13 \%$ to $17 \%$ \\
\hline $\begin{array}{l}\text { Reported } \\
\text { Cost }(\$ / \mathrm{kW})\end{array}$ & $>\$ 600$ & $>\$ 2500$ & $>\$ 2500$ & $>\$ 2000$ \\
\hline
\end{tabular}

Sources: Thekdi 2011 and Harrell 2014.

711

712

713

714

715

716

717

718

719

720

721

722

723

724

725

726

727

Other technologies, such as thermoelectric generation, piezoelectric power generation, and thermionic generation, convert thermal energy directly to electricity (US DOE, 2008; EPRI, 2010). However, these technologies are still emerging and have not yet reached full commercialization for application in large-scale industrial plants.

The application of waste heat to power generation technologies will depend on a number of factors, such as the physical and chemical characteristics of the waste heat (e.g., temperature and chemical composition), cost-effectiveness, and physical space limitations.

\section{Conclusions}

China is the largest energy user and $\mathrm{CO}_{2}$ emitter in the world. The industrial sector consumes about $70 \%$ of China's energy where coal is the predominant fuel. As China strives to peak $\mathrm{CO}_{2}$ emissions around 2030 or earlier and plans to cap coal consumption, understanding, managing, and utilizing waste heat in China's industrial sector will support China in achieving its energy, environmental, and climate goals both domestically and internationally.

A review of existing studies on the waste heat potential in China shows that detailed technical analysis is lacking. Often, waste heat potential was reported without a transparent or 
standardized methodology. As a result, China's technical and practical potential for waste heat utilization is not clear. In addition, except for successful adoption in the cement sector, waste heat to power generation technologies have not been implemented widely in other energyintensive sectors in China.

732

By adopting two levels of temperature set points $\left(25^{\circ} \mathrm{C}\left[77^{\circ} \mathrm{F}\right]\right.$ and $\left.150^{\circ} \mathrm{C}\left[300^{\circ} \mathrm{F}\right]\right)$ and two levels of power generation equipment efficiency (practical efficiency and the Carnot Efficiency), this study analyzed the theoretical maximum potential and practical potential of waste heat in the cement, iron and steel, and glass sectors in China through a standardized thermal modeling method in addition to data collection, cross-examination of data, and expert interviews.

The results showed that as of 2012, the untapped practical potential to produce electricity from waste heat in the China's cement sector is about $1.3 \mathrm{GW}_{\mathrm{e}}$. With today's technologies, the cement industry can produce $28 \mathrm{kWh}$ of electricity per ton of clinker. The cement sector experience demonstrates the viability of waste heat to power generation technologies and also indicates the scalability in other sectors.

744

However, sectors with complex processes and various products, such as iron and steel, need to consider using waste heat as thermal energy rather than solely focusing on waste heat to power. This analysis focused on the waste heat potential of the blast furnace stove in the ironmaking process, and found the untapped waste heat to power generation potential in this process is about $205 \mathrm{MW}_{\mathrm{e}}$, which is about $3 \mathrm{kWh}$ of electricity per ton of iron based on 2012 production levels in China.

In addition, this analysis found that sectors such as glass and cement are favorable for implementing easily adopted and cross-sector waste heat to power technologies such as the Steam Rankine Cycle and the Organic Rankine Cycle. These sectors share similar characteristics, include producing a homogenous product, relatively short and simple processes, medium-high exhaust gas temperatures, fewer contaminants in the heat stream, and low penetration of waste heat to power generation technologies.

The glass sector, even though it has a smaller energy profile compared to the cement and iron and steel sectors, showed the highest waste heat to power generation potential on a per unit of production basis - $46 \mathrm{kWh}$ of electricity per ton of glass. The total untapped practical potential to produce electricity from waste heat in glass sector is $190 \mathrm{MW}$. However, the current penetration rate of waste heat to power generation technologies in the glass sector in China is very low, at about $10 \%$. In order for the glass sector to realize its high potential, identifying and understanding the barriers to implementation of the technology in this sector is critical.

\section{$766 \quad 7 . \quad$ Limitations and Future Research}

\section{1. $\quad$ Limited research scope}


This research was limited in scope to three industrial sectors, to waste heat from exhaust gases, and to utilization of waste heat to produce power.

This research estimated the technical potential of waste heat in three selected industries, with an emphasis on waste heat potential from exhaust gas, because exhaust gas is the largest potential area of waste heat recovery. There are other sources of waste heat that exist in industrial facilities, such as heat loss through furnace walls, conveyor belts, poor insulation, unusual leakages, and openings. Sensible heat from slag and manufactured industrial products is another area of emerging waste heat recovery. However, this analysis focused solely on exhaust gas waste heat.

This research chose to focus on waste heat to power generation, because electricity can be used in all sectors and can be relatively easily and inexpensively transported in China. However, a significant amount of the waste heat potential will remain in the form of heat. How to make best use of the low temperature waste heat is an important energy and policy question that deserves more research and policy attention. More work is needed to understand the barriers and opportunities in utilizing medium to low temperature industrial waste heat. industry. However, it is almost impossible to conduct such an analysis at the plant level given the lack of publically available information. This posed limitations in understanding location specific conditions. This research reduced this limitation by disaggregating the sector as much as possible by waste heat temperature, technology, project size, and efficiency levels.

\subsection{Potential biases in assumptions}

794 To determine fuel use by industry, this research used minimum energy performance standards (MEPS) published by the Chinese government. This research used the average values between the 2008 and 2013 standards for the baseline values in 2012. However, the enforcement rate of the minimum energy performance standards may not be $100 \%$ and could vary by industry. Using the prescribed minimum energy efficiency levels for existing plants provides a lowerbound estimate of the total available waste heat potential.

This research analyzed waste heat potential by technology type. For example, both NSP kilns and non-NSP kilns were considered in the cement sector. However, when a technology penetration breakdown was not available (as in the glass sector), this research assumed that the Chinese plants use a better technology (e.g., regenerative furnaces in the glass sector). This assumption is based on the fact that the Chinese "phasing out" program has been closing down small and old furnaces and equipment since 2006 and most of the Chinese furnaces are relatively new (built or retrofitted in the last 10-15 years). But a better technology does lead to a lower estimate of the available potential waste heat. This means the research results are conservative. 
810 A key parameter used in the analysis is exhaust temperature, which varies by sector,

811 technology, energy and material inputs, and technical operations. It is very difficult to use only

812 one exhaust temperature to represent the whole industry. Exhaust temperatures used in this

813 analysis are based on previous reports published by the U.S. Department of Energy and expert

814 interviews. These sources tend to provide a better than average condition, which means lower

815 exhaust gas temperatures. This may lead the results to reflect a lower-bound estimate of total

816 available waste heat potential.

$817 \quad$ 7.4. Future research

818 This study analyzed the waste heat potential of three industrial sectors in China using a

819 standardized methodology. In the future, this method can be applied to assess other energy-

820 intensive sectors such as ammonia, caustic soda, non-ferrous metals, and sulfuric acid.

821

822

823

Previous studies have found significant waste heat potential in the three Chinese industries

824

825 analyzed in the research described in this paper. ERI (2011) estimated that in 2010 there was about 29 million tonnes of coal equivalent (Mtce) [850 PJ] waste heat potential in the Chinese ammonia industry, 16 Mtce (469 TJ) waste heat potential in the Chinese sulfuric acid industry, 12 Mtce (352 PJ) waste heat potential in the Chinese calcium carbide industry, and 3.9 Mtce (114 PJ) waste heat potential in the Chinese caustic soda industry. Dong (2013) estimated that about $60 \%$ of total energy use in the refining process of China's non-ferrous industry is converted to waste heat. By focusing on waste heat to power generation, Lu (2010) and Dong (2013) also estimated that the market potential of coke dry quenching technologies (the main means of waste heat recovery in the coke industry) could reach $1 \mathrm{GW}$.

832

In addition, the methodology described in this paper can be used in countries other than China, such as Brazil and India, to better understand the international potential for use of waste heat. Applying a transparent and consistent methodology across sectors can help researchers and policy makers to compare results across industries to identify gaps and action priorities.

Future research can also focus on assessment of the waste heat potential analysis at a deeper level. For example, sampling of industrial companies to collect detailed plant-level data would provide more accurate information related to a number of assumptions, such as exhaust gas temperatures and technology adoptions. This type of industry-level deep analysis can provide

842 higher resolution results, such as identifying waste heat potential by exhaust gas grades and providing tailored recommendations to the studied industry.

Analysis related to low-temperature waste heat utilization potential in China is needed. This study provides a first assessment of the total aggregated energy potential of the low-

847 temperature waste heat. Future research on technologies, materials, and system designs to 848 utilize low-temperature waste heat is needed.

850 Cross-sector (between the industrial sector and building, urban systems) analysis, such as

851 industrial park system optimization, cascading use of energy in urban cities, and optimal 
852 locations of industrial facilities, is also needed to help China achieve low-carbon, sustainable

853 urbanization development.

854

855 Finally, policy analysis is needed on how to integrate waste heat utilization in China's energy

856 and climate goals. Such efforts could include formulating industry or national standards on

857 quantifying waste heat potential and savings from implementing waste heat to power

858 generation projects or designing policy mechanisms to recognize waste heat potential as "non-

859 fossil equivalent" in order to incorporate waste heat savings into China's non-fossil targets.

\section{8. Acknowledgments}

861 This work was supported by the U.S. Department of Energy and the Energy Foundation China

862 through the Department of Energy under contract No.DE-AC02-05CH11231.

863

864 The authors would like to thank Dr. Greg Harrell, Dr. Duncan Callaway, and Dr. Hector Cardenas

865 for their review and comments.

9. References

867 Administration of Quality Supervision, Inspection and Quarantine of China (AQSIQ) and the

868 Standardization Administration of China (SAC). 2012. "The norm of energy consumption per

869 unit products of cement (GB 16780-2012)”. December 31. [Chinese text]

870 Administration of Quality Supervision, Inspection and Quarantine of China (AQSIQ) and the 871 Standardization Administration of China (SAC). 2008. "The norm of energy consumption per 872 unit products of flat glass (GB 21340-2008)". January 9. [Chinese text]

873 Administration of Quality Supervision, Inspection and Quarantine of China (AQSIQ) and the 874 Standardization Administration of China (SAC). 2013. "The norm of energy consumption per 875 unit products of flat glass (GB 21340-2013)". December 18. [Chinese text]

876 Brückner, S., Liu, S., Miró, L., Radspieler, M., Cabeza, L.F., Lävemann, E. 2015. “Industrial waste 877 heat recovery technologies: An economic analysis of heat transformation technologies,"

878 Applied Energy, 151, pp. 157-167.

879 China Cement Association (CCA). 2008. China Cement Almanac 2007. March. China Building 880 Materials Industry Press. Beijing, China.

881 China Cement Association (CCA). 2009. China Cement Almanac 2008. January. China Building 882 Materials Industry Press. Beijing, China.

883 China Cement Association (CCA). 2010. China Cement Almanac 2009. April. China Building 884 Materials Industry Press. Beijing, China.

885 China Cement Association (CCA). 2011. China Cement Almanac 2010. April. China Building 886 Materials Industry Press. Beijing, China. 
887 China Cement Association (CCA). 2012. China Cement Almanac 2011. April. China Building 888 Materials Industry Press. Beijing, China.

889 China Cement Association (CCA). 2014. China Cement Almanac 2012-2013. March. China

890 Building Materials Industry Press. Beijing, China.

891 China Economic Net. 2007. "Energy consumption of flat glass manufacturing industry increases 892 compared to 2006", August 31.

893 http://www.ce.cn/cysc/ny/hgny/200708/31/t20070831 12746858.shtml [Chinese text]

894 [Accessed on January 29, 2015]

895 China National Institute of Standardization (CNIS), 2013. Implementation Guide on the Energy

896 Management System of Flat Glass Industry in China. November 6.

897 http://www.cnis.gov.cn/wzgg/201311/P020131129270028408720.pdf [Accessed on February

898 9, 2015] (Chinese text)

899 China State Council. 2012. "Twelfth Five-Year Plan of Energy Conservation and Emission

900 Reduction", August 6. [Chinese text] http://www.gov.cn/zwgk/2012-

901 08/21/content_2207867.htm

902 China State Council. 2013. "Notice on Releasing 'Atmospheric Pollution Prevention Action

903 Plan'”, September 10. [Chinese text]. http://www.gov.cn/zwgk/2013-

904 09/12/content 2486773.htm

905 Cook, E. 1971. "The flow of energy in an industrial society", Scientific American 225(4),

906 September.

907 Dong, Y. 2013. “Industrial waste heat utilization in China”. Peking University. CCED Working

908 Paper Series. No. 20130505. April. [Chinese text]

909 Editorial Board of China Steel Yearbook. 2013. China Steel Yearbook 2013. China Iron and Steel

910 Association. Beijing, China.

911 Electric Power Research Institute (EPRI). 2010. "Waste Heat Recovery in Industrial Facilities:

912 Opportunities for Combined Heat and Power and Industrial Heat Pumps". 1020134. Technical

913 Update, December.

914 Energetics, Inc. and E3M, Inc. 2004. Energy Use, Loss and Opportunities Analysis: U.S.

915 Manufacturing \& Mining. December.

916 Energy Research Institute of China (ERI). 2011. Surveys and Analysis of Industrial Waste Heat

917 Resource Utilization. December. [Chinese text]

918 European Commission. 2013b. Best Available Techniques (BAT) Reference Document for the

919 Manufacture of Iron and Steel Production. JRC 69967. EUR 25521 EN.

920 Frost \& Sullivan. 2010. “Executive Summary: Waste Heat Recovery Opportunities in Selected US 921 Industries". 
922 Harrell, G. 2014. Personal interview on January 28, 2015.

923 Huang, D. 2013. "System energy conservation, advanced technologies: to support the green

924 manufacturing of iron and steel industry development", Presentation at the International

925 Seminar on Iron and Steel Technology Application and Energy System Optimization. July 31 -

926 August 1. China Iron and Steel Association. [Chinese text].

927 Institute for Industrial Productivity (IIP). 2014. "Industrial Efficiency Technology Database:

928 Glass". http://ietd.iipnetwork.org/content/glass\#technology-resources [Accessed on January

929 29, 2015]

930 Intergovernmental Panel on Climate Change (IPCC). 2006. 2006 IPCC Guidelines for National

931 Greenhouse Gas Inventories: Volume 2. http://www.ipcc-

932 nggip.iges.or.jp/public/2006gl/pdf/2 Volume2/V2 1 Ch1 Introduction.pdf

933 Lawrence Berkeley National Laboratory (LBNL) and China Building Materials Academy (CBMA).

934 2012. "Comprehensive Program to Improve Energy Efficiency, Increase the Use of Alternative

935 Fuels and Raw Materials, and Reduce Emissions in the Cement Sector in China", Final Report for

936 Asia Pacific Partnership Project.

937 Lu, B. 2010. "Current Status of Waste Heat to Power in China and Analysis of Development

938 Trends", China Building Materials. November, pp100-103. [Chinese text]

939 Lu, H. 2015. Capturing the Invisible Resource: Analysis of Waste Heat Potential in Chinese

940 Industry and Policy Options for Waste heat to Power Generation. Lawrence Berkeley National

941 Laboratory (Report Number: LBNL-179618). Berkeley, California.

942 Ma, G., J. Cai, W. Zeng, and H. Dong. 2012. "Analytical Research on Waste Heat Recovery and

943 Utilization of China's Iron and Steel Industry", Energy Procedia 14, 1022-1028.

944 Ministry of Industry and Information Technology of China (MIIT). 2011a. "Building Materials

945 Industry Development Plan during the Twelfth Five-Year (2011-2015)". November $8^{\text {th }}$.

946 http://www.miit.gov.cn/n11293472/n11293832/n11293907/n11368223/14335483.html

947 [Accessed on January 21, 2015]

948 Ministry of Industry and Information Technology of China (MIIT). 2011b. "Cement Industry

949 Development Plan during the Twelfth Five-Year (2011-2015)". November $8^{\text {th }}$.

950 http://www.miit.gov.cn/n11293472/n11293832/n11293907/n11368223/14335483.html

951 [Accessed on January 21, 2015]

952 Ministry of Industry and Information Technology of China (MIIT). 2011c. "Iron and Steel

953 Industry Development Plan during the Twelfth Five-Year (2011-2015)". October 24 ${ }^{\text {th }}$.

954 Ministry of Industry and Information Technology of China (MIIT). 2014. "Iron and Steel Industry

955 Economy Operation Conditions in 2013". February 21.

956 http://www.miit.gov.cn/n11293472/n11293832/n11294132/n12858402/n12858492/15891265

957 .html [Accessed on February 24, 2015] 
958 Miró, L., Brückner, S., Cabeza, L.F. 2015. “Mapping and discussing Industrial Waste Heat (IWH) 959 potentials for different countries," Renewable and Sustainable Energy Reviews, 51, 4573, pp.

960 847-855.

961 National Bureau of Statistics of China (NBS). 2013a. China Energy Statistical Yearbook 2013.

962 December. China Statistics Press. Beijing, China.

963 National Bureau of Statistics of China (NBS). 2013b. China Statistical Yearbook 2013.

964 September. China Statistics Press. Beijing, China.

965 National Energy Technology Laboratory (NETL). 2013. "Technology Development for

966 Supercritical Carbon Dioxide (SCO2) Based Power Cycles", U.S. Department of Energy.

967 http://www.netl.doe.gov/research/coal/energy-systems/turbines/supercritical-co2-power-

968 cycles [Accessed on March 9, 2015]

969 Oluleye, G., Jobson, M., Smith, R., Perry, S.J. 2015. "Evaluating the potential of process sites for

970 waste heat recovery," Applied Energy, in press.

971 Pacific Northwest National Laboratory (PNNL). 2006. Opportunity Analysis for Recovering

972 Energy from Industrial Waste Heat and Emissions. April. PNNL-15803.

973 Pehnt, M., J. Bödeker, E. Jochem, F. Idrissova, and M. Arens. 2011. "Industrial waste heat 974 tapping into neglected efficiency potential". Proceedings in the 2011 European Council for an 975 Energy-Efficient Economy Summer Study. Toulon/Hyères, France.

976 Podesta, J. and J. Holdren. 2014. "The U.S. and China Just Announced Important New Actions to 977 Reduce Carbon Pollution", November 12. The White House Blog.

978 http://www.whitehouse.gov/blog/2014/11/12/us-and-china-just-announced-important-new-

979 actions-reduce-carbon-pollution

980 Price, L., A. Hasanbeigi, H. Lu, and L. Wang. 2009. Analysis of Energy-Efficiency Opportunities for 981 the Cement Industry in Shandong Province, China. Lawrence Berkeley National Laboratory 982 (LBNL-2751E-Rev). Berkeley, California. http://china.lbl.gov/sites/all/files/lbl-2751e-shandong983 cementoct-2009.pdf

984 Sina News. 2012. "Glass and glass products industry grew 28.2\% in 2011", March 13.

985 http://news.dichan.sina.com.cn/2012/03/13/454360.html [Chinese text] [Accessed on January $98629,2015]$

987 Sollesnes, G. and H. E. Helgerud. 2009. Potensialstudie for utnyttelse av spillvarme fra norsk 988 industry (Survey of potentials for exploitation of waste heat from Norwegian industry). July 1. 989 https://www.etde.org/etdeweb/servlets/purl/952328-2WBS5U/952328.pdf [Accessed on 990 January 26, 2015]

991 The White House. 2014. "FACT SHEET: U.S.-China Joint Announcement on Climate Change and 992 Clean Energy Cooperation", November 11. https://www.whitehouse.gov/the-press-

993 office/2014/11/11/fact-sheet-us-china-joint-announcement-climate-change-and-clean-energy-c 
994 Thekdi, Arvind. 2011. "Waste Heat Recovery for Process Heating Equipment", Presentation at 995 the Workshop on Industrial Process Heating Systems. Zhengzhou, Henan Province, China.

996 October 12-14.

997 U.S. Department of Energy (US DOE). 2008. Waste Heat Recovery: Technology and 998 Opportunities in the U.S. Industry. Industrial Technologies Program. Prepared by BCS, 999 Incorporated. March.

1000 U.S. Environmental Protection Agency (US EPA). 1984. Industrial Waste Heat Recovery and the 1001 Potential for Emissions Reduction. Project Summary. March.

1002 http://infohouse.p2ric.org/ref/14/13882.pdf [Accessed on January 26, 2015]

1003 U.S. Geological Survey (USGS). 2014a. "Preliminary Release of the 2012 Annual Tables for 1004 Cement", June 27. http://minerals.usgs.gov/minerals/pubs/commodity/cement/myb1-20121005 cemen-pre.xls [Accessed on January 20, 2015]

1006 U.S. Geological Survey (USGS). 2014b. “Mineral Yearbook: Iron and Steel”, September 22. 1007 http://minerals.usgs.gov/minerals/pubs/commodity/cement/myb1-2012-cemen-pre.xls 1008 [Accessed on January 20, 2015]

1009 Wang, Chenya. 2011. “Energy Conservation of Glass Melting Furnaces in China”. Glass Melting 1010 Furnace Committee of China Energy Conservation Association. [Chinese text]

1011 Wang, L. and R. Li. 2001. "Typical kinds of coal in China and some special coals with their fly ash 1012 difficult to precipitate by ESP", Presented at the $8^{\text {th }}$ International Conference on Electrostatic 1013 Precipitation. May 14-17.

1014 Worrell, E., C. Galitsky, E. Masanet, and W. Graus. 2008. Energy Efficiency Improvement and 1015 Cost Saving Opportunities for the Glass Industry: An Energy Star Guide for Energy and Plant 1016 Managers. Lawrence Berkeley National Laboratory (LBNL-57335-Revision), Berkeley, California. 1017 March.

1018 Zhou, F. 2012. "Significant Potential in Industrial Waste Heat Resource Development and 1019 Utilization", Macroeconomic Management (9), 43-44. [Chinese text] 